\title{
Study of Upper Albian rudist buildups in the Edwards Formation using ground-based hyperspectral imaging and terrestrial laser scanning
}

\author{
Diana Krupnik $^{1}$ Shuhab Khan ${ }^{1}$ Unal Okyay ${ }^{1}$ Preston Hartzell ${ }^{2}$ Hua-Wei Zhou ${ }^{1}$ \\ ${ }^{1}$ University of Houston Department of Earth and Atmospheric Sciences \\ ${ }^{2}$ University of Houston Department of Civil and Environmental Engineering
}

Abstract

Ground-based hyperspectral imaging is used for development of digital outcrop models which can facilitate detailed qualitative and quantitative sedimentological analysis and augment the study of depositional environment, diagenetic processes, and hydrocarbon reservoir characterization in areas which are physically inaccessible. For this investigation, ground-based hyperspectral imaging is combined with terrestrial laser scanning to produce mineralogical maps of Late Albian rudist buildups of the Edwards formation in the Lake Georgetown Spillway in Williamson County, Texas. The Edwards Formation consists of shallow water deposits of reef and associated interreef facies. It is an aquifer in western Texas and was investigated as a hydrocarbon play in south Texas. Hyperspectral data were registered to a geometrically accurate laser point cloudgenerated mesh with sub-pixel accuracy and were used to map compositional variation by distinguishing spectral properties unique to each material. More calcitic flat-topped toucasid-rich bioherm facies were distinguished from overlying porous sucrosic dolostones, and peloid wackestones and packstones of back-reef facies. Ground truth was established by petrographic study of samples from this area. This research integrates high-resolution datasets to analyze geometrical and compositional properties of this carbonate formation at a finer scale than traditional methods have achieved and to model the geometry and composition of rudist buildups.

(C) 2016. This manuscript version is made available under the Elsevier user license http://www.elsevier.com/open-access/userlicense/1.0/ 
KEYWORDS: 3D mapping, Carbonate, Ground-based hyperspectral sensors, Terrestrial Laser Scanner

\section{Introduction}

\subsection{Overview}

This work seeks to utilize ground-based as well as laboratory-based hyperspectral imaging (also referred to as imaging spectroscopy) to map mineralogical variation and facilitate the study of diagenetic features in rudist buildups and associated interreef and backreef facies. Carbonate minerals dominate these deposits with minor amounts of silica (Chen et al., 2016; Nelson, 1973).

Digital outcrop models, a recently developed technique for detailed geologic studies, are produced in this work. These methods can augment our understanding of hydrocarbon reservoir properties and enhance subsurface models by providing a realistic example of stratigraphic horizons, facies distributions, and compositional variation (Pringle et al., 2006). Integrated ground-based remote sensing techniques can provide information about compositional and textural variability of exposed rock (Kurz et al., 2013; Minisini et al., 2014). Observation of facies architecture at outcrop scale is useful for the purpose of observing diagenetic features and pathways for fluid flow.

Hyperspectral imaging is used to delineate compositional variation of exposed rock in regional studies using an airborne platform (Baugh et al., 1998; Bell et al., 2010; Bellian et al., 2007; Bowen et al., 2007; Roach et al., 2006), in the laboratory setting (Baissa et al., 2011; Greenberger et al., 2015), and more recently using close range ground based sensors (Kurz et al., 2012; Murphy, 2015; Okyay and Khan, 2016). While high resolution 
imaging can provide information from a distance, it lacks three dimensionality and contains some level of distortion. Light detection and ranging (LiDAR) has been used for several decades for purposes of surveying, atmospheric science, military, and many other applications, but only in the last decade has it gained popularity for the purpose of creating digital outcrop models (Pringle et al., 2006). The geometrically accurate data collected using a terrestrial laser scanner (TLS), a ground-based LiDAR system, can be augmented by hyperspectral data which contains reflectance values over a wide spectral range and can be used to distinguish between different minerals. In recent studies, three dimensional outcrop models have been generated by combining ground based hyperspectral and TLS data and were used to analyze compositional and geometric properties of exposed rock (Bellian et al., 2007; Snyder et al., 2016). Ground based hyperspectral and TLS sensors can be instrumental in producing a user-friendly interface for geological investigation.

\subsection{Regional and Site Geology}

During the Cretaceous, a warm shallow marine environment led to the formation of several reef bodies including the Stuart City, Central Texas, and Devil's River reef trends the extent of which is shown in Figure 1. These deposits produced an arcuate wedge of carbonate rocks which thickens toward the Gulf of Mexico and thins toward the northwest (Rose, 1974). Rudist buildups are found along the Central Texas and Devil's River Reef trends. The focus of this study is the Edwards Formation, which consists of about 90 to 105 meters (300 to 340 feet) of limestone accumulated on the Comanche shelf (Rose, 1974). The study area is in close proximity to the Kirschberg Lagoon which is known to contain evaporate minerals (Fisher and Rodda, 1969). 
High porosity and permeability of the Edwards Limestone create a pathway for fluid flow. It is an aquifer system which stretches for a distance of more than $290 \mathrm{~km}$ in south central Texas and provides water supply to over 2 million people (Johnson, 2014) and is a prolific hydrocarbon play as well (Fritz et al., 2000; Moredock and Van Ciclen, 1964). Rudist reefs and collapse breccias constitute permeable zones in the Edwards limestone (Maclay, 1986).

In some parts of the world, rudist buildups are prolific hydrocarbon reservoir formations, examples include the Shuaiba Formation in northwest Oman (Borgomano et al., 2002), the Mishrif Formation in the Mesopotamian Basin in southern Iraq (Sadooni , 2005), and the Raman Field in Southeast Turkey (Keskin and Can, 1986).

Rudist bioherms are widespread in this area and diagenetic alteration is prevalent including but not limited to dolomitization, silicification, compaction, and dedolomitization. Fisher and Rodda (1969) noted varied dolomite fabrics in the Edwards, including stratal and massive dolomite. Stratal dolomite consists of poorly developed intergrown crystals less than $10 \mu \mathrm{m}$ in diameter and has low porosity and permeability. Massive dolomite consists of loosely distributed euhedral (planar-e) crystals mostly larger than $30 \mu \mathrm{m}$ and high porosity and permeability. It generally replaces fossiliferous limestones as evidenced by relict structures such as fossil molds and casts. Massive dolomite commonly is overlain by evaporite-solution units (Fisher and Rodda, 1969). Relation of dolomites with evaporate units as well as stable isotopic studies suggest that these dolomites resulted from metasomatic replacement of calcium carbonate as a result of contact with magnesium-enriched lagoonal brines, suggesting seepage reflux dolomitization (Fisher and Rodda, 1969; Tucker and Wright, 1990; Welch, 2001). 
The present investigation took place in the Lake Georgetown Spillway (LGS) in Williamson County, Texas (Figure 2), where rudist buildups of the Cretaceous Edwards formation outcrop along the relatively fresh surface of the spillway walls, constructed in 1979 (TWDB 2015). A transgressive-regressive depositional package containing the upper portion of the Edwards is exposed at this location, containing a rare three dimensional view of middle Albian rudist communities. Sullivan and Zahm (2005) observed a variety of carbonate facies above the floor of LGS including evaporitic back reef facies with thin beds of laminated wackestones and packstones, a $1 \mathrm{~m}$ bed of vertically burrowed brown dolomite, and rudist bioherms consisting of toucasid and caprinid-toucasid-radiolitid-chrondrodont buildups flanked by interreef debris deposits. Just below the floor of the spillway, caprinid mounds composed of packstones to grainstones can be recognized by their grainstone caps which are preserved due to their resistant nature.

Figure 1. (A) Cretaceous paleogeography of central Texas and surrounding areas after Damman (2011);

Fisher and Rodda (1969); (B) geologic map, C) stratigraphic column, and (D) cross section of the Lake Georgetown area in Williamson County after Collins (2005) and Chen et al. (2016).

Figure 2. A) Location of the vertical rock face which was scanned along the eastern wall of Lake Georgetown Spillway. B) Oblique image is looking northeast; the approximate extent which was scanned is outlined.

These have been studied by means of three-dimensional ground penetrating radar and were found to be high porosity flat-topped bioherms with average heights of $2.5-3 \mathrm{~m}$ and basal diameter of $15-25 \mathrm{~m}$ and onlapping as well as aggradational reef flank strata observed to be prograding toward the south (Mukherjee et al., 2010; Mukherjee et al., 2012). Mud-dominated facies consisting of burrowed mollusc wackestones and chalky 
skeletal limestones overlying transgressive packages of wackestones and mudstones with low abundances of marine fossils are seen at the base of the sequence and are exposed in stream gullies (Sullivan and Zahm, 2005). Rudist buildups of each type observed in LGS are relatively uniform as most bioherms consist of a dominant group: caprinids, toucasids, and caprinid-toucasid-radiolitids (Mukherjee et al., 2012). Toucasia is a group of rudists which are the dominant constituent of bioherms. In the present investigation, two rudist buildups, comprised of toucasid fossil material are captured in the imagery. These bivalves likely were gregarious reef builders, clinging to a firm substrate (Gili et al., 1995). In outcrop, they are seen as original and recrystallized shell fragments and few whole body fossils in a micrite matrix.

\subsection{Reflectance spectroscopy}

Carbonate rocks have distinctive absorption features around $2500-2550 \mathrm{~nm}$ and 2300 $2350 \mathrm{~nm}$, as shown in Figure 3, in the short wave infrared (SWIR) spectral range due to vibrational processes of the planar $\mathrm{CO}_{3}{ }^{2-}$ ions and are seen at longer wavelengths in calcite than in dolomite (Clark, 1999; Gaffey, 1987; van der Meer, 1994; Van der Meer, 1995). When using the ground based sensor under natural illumination, the absorption at $2300-2350 \mathrm{~nm}$ is most prominent, because others are obscured due to strong atmospheric absorption (Kaab, 2005).

Figure 3. Spectral curves of pure endmembers from Clark et al. (2007).

\subsection{Objectives}

The objectives of this study are to (i) map the lateral and vertical distribution of chert and carbonate minerals in outcrops of the Edwards Formation, and (ii) integrate outcrop-scale data and petrographic study to infer depositional environment and sequence of diagenetic events. 


\section{Methodology}

\subsection{Field data acquisition}

Ground-based hyperspectral data were acquired using two hyperspectral cameras of Spectral Imaging Ltd. (Specim), Finland. The first camera collects data in visible-near infrared (VNIR) region of the electromagnetic spectrum (EMS), whereas the second camera collects data in the shortwave infrared (SWIR) region. Both cameras are mounted on a rotating stage and tripod in which setting the outcrop image is created by rotating the cameras around an axis parallel to the sensors' optical axes, (push-broom scanning) (Figure 4). For this work emphasis is only on the SWIR data for classification due to the presence of characteristic absorption features of carbonates in the shortwave infrared wavelengths, which are the main constituent of this outcrop. The SWIR camera collects data from 256 distinct spectral bands between $1000 \mathrm{~nm}$ and $2500 \mathrm{~nm}$ with an average bandwidth (full width at half maximum) of $6.3 \mathrm{~nm}$. The forelens used on the SWIR camera provides $24^{\circ}$ vertical field-of-view (FOV) which results in image pixel size ranging from $12 \mathrm{~mm}$ to $41 \mathrm{~mm}$ at ranges between $9 \mathrm{~m}$ and $31 \mathrm{~m}$. Several hyperspectral images were collected from vertical rock exposures of the Lake Georgetown Spillway on November 8, 2014 between 2:10pm and 4:50pm under fairly clear-sky conditions. Each individual scan took approximately $45-60$ seconds to collect providing fairly uniform illumination across individual images. Nonetheless, some of the images showed slight change of illumination across-track. Therefore, only the images which do not show any significant brightness trend across-track were used for classification. Following each scan a dark image was collected using the same exposure time but with no incident light. During data collection a white reference panel made from polytetrafluoroethylene (PTFE) similar to Spectralon ${ }^{\circledR}$ was placed within sensor's 
field-of-view parallel to the orientation of the rock face for calibration purposes. Laser point cloud data were collected using a terrestrial laser scanner (TLS) (VZ-400) from Riegl Laser Measurement Systems GmbH (RIEGL-LMS), Austria. Four scan positions were acquired to ensure complete coverage of rock exposure. Initial orientation of hyperspectral cameras in each scan position was surveyed using TLS for precise location of camera orientation and position of the rotation axis.

Figure 4. Ground-based hyperspectral and terrestrial laser scanner data collection in the field.

\subsection{Petrography}

Polished thin sections were prepared from 18 samples collected in the area which was scanned by ground-based hyperspectral and TLS instruments. These were impregnated with blue epoxy for porosity estimation and stained using Alizarin red $\mathrm{S}$ for discrimination of calcite and dolomite. A petrographic microscope with a mounted digital camera (Nikon LV150) was used to produce thin section photomicrographs in plane and crossed polarized light.

\subsection{Endmember sample preparation}

Relatively pure examples of calcite, dolomite, and chert from locations shown in Table 1 were used for endmember preparation. In the similar manner to the use of published spectral libraries, these relatively pure examples were used in order to build a custom spectral library of mixtures with known compositions, which relies on the assumption that examples of minerals should have similar spectral curves i.e. similar distinctive absorption features regardless of their origin. These samples were crushed using a jaws crusher and shatter box, and sieved to a grain size fraction of 75-150 $\mu \mathrm{m}$. Mixtures with known abundances of endmembers (by mass) were prepared using a scale with $0.0001 \mathrm{~g}$ 
precision. Total mass for each sample was $3.5 \mathrm{~g}$ and samples which were prepared had percentages of endmember materials shown in Figure 5. A ternary diagram was used to guide selection of endmember abundances for optimal step-wise coverage. An Analytical Spectral Device (ASD) Fieldspec Pro spectroradiometer was used to measure spectra of these mixtures using a contact probe under artificial illumination. Minimum, depth, area, and asymmetry of the absorption feature at $2300-2350 \mathrm{~nm}$ were calculated as described by Van der Meer (1995).

Table 1. Origins of relatively pure mineral samples used for endmember preparation (Palache, 1937; Tangier Smith and Siebenthal, 1906; Vega and Lawton, 2011)

Figure 5. A) Ternary diagram showing motivation for mixture preparation (each point on the ternary diagram represents an endmember composition); B) Table showing composition of prepared endmember materials.

\subsection{Laboratory-based hyperspectral imaging}

Whole rock samples collected in the field were analyzed in the laboratory using the SWIR camera on a custom-made scanning stage. Rock samples were placed on a sample tray moving at a constant velocity approximately $50 \mathrm{~cm}$ from the camera fore-lens. The velocity of the stage can be adjusted based on the framerate set for the SWIR camera during data collection ensuring square image pixels. The samples were illuminated by four $50 \mathrm{~W}$ quartz-halogen lamps providing full spectrum artificial light (Figure 6). In the similar manner to field data collection a white reference panel was also scanned along with the rock samples for calibration purposes.

Figure 6. Setup for hyperspectral imaging in the laboratory setting. Cameras are mounted to the wall while specimens are placed on a moving stage. 


\subsection{Data processing}

\subsubsection{Hyperspectral image pre-processing and classification}

The hyperspectral images were mainly processed using standard tools available in ENVI 5.2 (Exelis Visual Information Solutions Inc.). Additionally, in-house solutions developed in the MATLAB 2014a (Mathworks Inc.) were used for pre-processing steps.

The hyperspectral images were first corrected for dark current, the response of the sensor in the absence of incident light. For this, the average dark image frame was calculated using the collected dark image and subtracted from each image frame. For relative reflectance conversion, the Empirical Line (EL) calibration was performed. The EL calibration aims to reduce atmospheric and illumination effects using laboratory and image spectra of known targets to calculate correction coefficients (Smith and Milton, 1999). Smith and Milton (1999) recommended using two to four targets with large spectral contrast (i.e. dark and bright targets) so as to calculate correction coefficients for better results, in which case band-wise linear regression is calculated by fitting a regression line through all the target spectra. In the absence of multiple reliable targets, however, only one spectrum can be used for EL calibration in ENVI, in which case the linear regression is assumed to pass through origin i.e. zero DN corresponds to zero reflectance. The reflectance spectrum of the white reference panel for the EL calibration was collected using an ASD Field Spec Pro spectroradiometer which was calibrated using Labsphere Spectralon $^{\circledR}$ diffuse reflectance standard. An ASD contact probe with an internal artificial light source was used during spectrum collection. Following the EL calibration, non-outcrop image pixels were masked out in order not to take these pixels into account for subsequent image classification. 
Maximum Noise Fraction (MNF) transformation (Green et al., 1988) was applied to relative reflectance image so as to separate the random noise in the hyperspectral data. As a result of MNF transformation, components are sorted based on their eigenvalues, higher values representing spatially coherent (noise-free) data. Focusing only on the spatially coherent component an inverse MNF transformation was applied to backtransform the data into the spectral domain.

Continuum removal was used to isolate a specific absorption feature, reducing the effects of illumination (Clark, 1981; Clark and King, 1987; McCord et al., 1981). Reflectance spectra are normalized to compare spectra of materials from a common baseline. The continuum is calculated by fitting straight line segments through local spectral maxima. The spectra are then divided by the continuum for each pixel in the image as described in Clark and Roush (1984). Continuum removal was applied to spectra after an inverse MNF rotation for wavelengths ranging from 2146 to $2390 \mathrm{~nm}$.

The hyperspectral images were classified using the Spectral Angle Mapper (SAM) (Kruse et al., 1993) image processing algorithm. The SAM has been used for hyperspectral and multispectral image classification as it provides an easy and rapid way for mapping spectral similarities between the image and reference spectra. The SAM treats reference spectra and image pixel spectra as vectors in a space with dimensionality equal to the number of bands in the data ( $\mathrm{n}$-dimensional space) and measures the angle between them in radians where smaller angle represents closer match i.e. more similarity between reference and image pixel spectra. In SAM, only the direction of these vectors is considered, not magnitude, so this method is relatively insensitive to illumination effect (Kruse et al., 1993), which is one of its main advantages. In this case, a threshold of 0.1 radians was used. Input wavelengths between 2146 and $2390 \mathrm{~nm}$ were isolated 
for the purpose of classification due to the location of the diagnostic absorption feature of carbonate minerals (Hecker et al., 2008). Accuracy of classification products was assessed by preparing a confusion matrix from ground truth ROIs, which were digitized using known locations of sample collection (documented by photography during field campaigns). Confusion matrices were used to calculate kappa coefficient for each hyperspectral scan. SAM classification was done using 3 different types of endmember selection: endmember spectra selected from remote sensing imagery in locations where the lithology was sampled, the average spectrum of whole rock samples, determined by laboratory imaging spectroscopy, and relatively pure endmember materials and mixtures prepared in the laboratory.

\subsubsection{TLS}

Separate scans from different positions were referenced to a common coordinate system using multi-station adjustment (Schneider, 2009). Points which do not correspond to rock outcrop were removed manually, and octree and deviation filters were applied to remove point redundancy and decrease density of points, respectively (Bornaz and Rinaudo, 2004; Vosselman and Maas, 2010). Deviation gate filtering was used to remove points which correspond to a pulse with a large difference in shape with respect to the emitted pulse. Octree filtering structures data based on a cube which is divided into 8 equally sized cubes which are again divided until a user-specified base cube size is reached (Lai et al., 2014; Meagher, 1980). Isolated points are eliminated by removing cells which contain only one point. A mesh was created by fitting triangles to points by Poisson surface reconstruction (Kazhdan et al., 2006).

\subsubsection{Registration of Hyperspectral and LiDAR Data}


Hyperspectral imagery was registered to a meshed surface created from the TLS point cloud, using algorithms based on the geometric model by Huang et al. (2008). Camera interior and exterior parameters were calculated based on the locations of common points in hyperspectral and TLS data as described by Kurz et al. (2013). Retro reflective cylinder targets were used as common points as well as natural surfaces which are recognizable in both datasets. Error of registration (determined by pixels of hyperspectral imagery) was below 0.8 of one pixel which corresponds to approximately $32 \mathrm{~mm}$ at the greatest range. Once hyperspectral imagery was registered, the same parameters for a particular scene were used to register classification products to TLS data. The triangulated mesh derived from the LiDAR point cloud is textured with hyperspectral classification products. The textured mesh is visualized and measurements are made in RiSCAN Pro software v2.1 (RIEGL Laser Measurement Systems $\mathrm{GmbH}$ ).

\section{Results}

\subsection{Petrography}

Petrographic studies reveal compositional variability within rudist mounds as well as interreef areas; examples shown in Figure 7. The predominant compositions found in this outcrop are calcite, dolomite, and chert. At the base of the sequence, facies are micritic and have low porosity, with calcite as the dominant mineralogy. Chert nodules are found near the base and contain relict shell material. Overlying this layer, resistant beds of fossiliferous limestone were observed, mainly comprised of original and diagenetic calcite. Dolomitization and subsequent dedolomitization are evident, but dolomite comprises less than $25 \%$ of this layer. At the tops of the bioherms, original rudist fossil material is absent, as all shell material has been replaced by brown dolomite 
comprised of euhedral and subhedral crystals. Dedolomitization and calcitization is observed in these facies. Above the dolostone are resistant beds of micritic, foraminifera-containing packstones. Foraminiferal tests are replaced by calcite and dolomitization can be seen in the matrix as well as replacing some of the calcite.

Figure 7. Thin section photomicrographs. A, B, C, D, and F are in plane polarized light, whereas $E$ is in crossed polars to show chert cementation. (A) Silicified (arrows) fossiliferous packstone. Fossil material is abundant and porosity exists where dolomite rhombs were dissolved. Sample was collected from base of bioherm. (B) High porosity wackstone to packstone with abundant dolomite dissolution (arrows). This sample was collected near the top of the bioherm. (C) Porous dolostone containing secondary calcite cementation (arrows), collected from the flank of the bioherm (D) Wackstone with dolomitization of spar cement(yellow arrows) infilling recrystallized foraminifera (red arrow), collected from facies overlying the dolostone (E) Chert-cemented dolostone with varying degrees of dedolomitization and calcitization (yellow arrows); chert cement in contact with dolomite crystals (red arrows). (F) Fine-grained porous dolostone (yellow arrows) with a small amount of spar cementation (red arrows).

\subsection{Laboratory Spectroscopy}

\subsubsection{Prepared mixtures}

Laboratory spectroscopy measurements of endmember mixtures prepared in the laboratory (Figure 8) show shifting of the minimum of the absorption feature located at 2200-2350 nm (Figure 8B) and decreasing depth (Figure 8C) of this feature with increasing abundance of silica.

Figure 8. A) Spectra of endmembers prepared in the laboratory used for classification (result shown in figures 10 and 13b). B) Spectral parameters of absorption feature in wavelength range of 2000-2400nm C) Depth of absorption feature vs. relative abundance of silica.

\subsubsection{Whole rock samples}


Similarly, laboratory spectroscopy measurements of whole rock samples (Figure 9) show shifting of the characteristic carbonate absorption feature (located between 2200-2350 $\mathrm{nm}$ ) to shorter wavelengths with increasing dolomite abundance. Variability within each rock sample can be seen in Figure 9, as well as relative mineralogical abundance of samples collected in the area are presented from SAM classification (Table 2).

Figure 9. Average spectral curves of samples collected in the study area, analyzed using SWIR sensor in the laboratory. These were also used as endmembers for classification as shown in Figure 11.

Table 2. Percentages of endmember materials calculated from SAM classification in samples shown in Figure 10.

Figure 10. Laboratory imaging spectroscopy of whole rock samples. 1a-10a: false color composites showing bands associated with the following wavelengths: 2378,2334 , and $2146 \mathrm{~nm} ; 1 \mathrm{~b}-10 \mathrm{~b}$ are SAM classified images using spectra of laboratory prepared mixtures. White scale bars represent $2 \mathrm{~cm}$. Rudist shell fragments can be observed in $3 a$ and $3 b$ and $4 a$ and $4 b$ containing a mixture of calcite and dolomite infill, as well as minor amounts of chert in $4 \mathrm{a}$ and $4 \mathrm{~b}$.

\subsection{Ground-based remote sensing}

VNIR image displaying RGB true color composite (Figure 11A) and false color composite image showing SWIR RGB bands (Figure 11B) show full extent of study area registered to surface mesh. These images do show dolomitization and bioherm geometry, however, classification using SAM allowed for more detailed mineralogical mapping of the outcrop (Figure 12B, 13, and 14B and C). Knowledge of mineralogical distribution of two toucasid bioherms as well as back reef facies allows for enhanced interpretation of 
diagenetic features. Above the floor of LGS, massive limestone, dolostone, chertcemented dolostone, fossiliferous limestone, chert nodules, and carbonate nodules are included in hyperspectral data and can be seen in three dimensions in the LiDAR data. Overall, the composition becomes increasingly dolomitic up section (Figures 13 and 14), with dolomitized foraminiferal packstone near the top. The top layer has a lower percentage of dolomite than the porous, highly dolomitized, and in some places chert cemented dolostone.

The upper parts of the rudist mounds are mostly dolomitized and bioturbated. A horizon of chert nodules is seen approximately $0.5-1 \mathrm{~m}$ above the spillway floor in fossiliferous packstone as well as overlying dolostone layers (Figure 12). Chert nodules occur in reef as well as interreef deposits. Thinly-bedded calcite-rich limestone deposits are erosionally truncated toward the center of the mound (Figures 12 and 14), presumably because these have come into contact with dolomitizing fluids. Carbonate nodules (Figure 13) occur in the northwestern-most part of the scan and are associated with evaporitic backreef facies. Degree of dolomitization increases toward the southeast up to the smaller neighboring bioherm. Further southeast, dolomitic beds pinch out, and calcite-rich limestone is the main constituent. The dolomitized zone is relatively continuous and could reveal the paleo-flow pathway of dolomitizing fluids. Accuracy of classification, as determined by preparation of a confusion matrix, was 85,86 , and $80 \%$ for scan 1, 2, and 3, respectively, when samples prepared in the laboratory were used as endmembers. This yields kappa coefficients of $0.8212,0.8328$, and 0.6917 for scans 1,2 , and 3 , respectively. When samples collected from the outcrop were used as endmembers for classification, accuracy of classification was $92 \%$ for scan 1 and $93 \%$ for scan 2 with kappa coefficients of 0.8910 and 0.8823 . Scan 3 was not classified using 
endmembers produced from sample spectra, because few samples were collected in this area.

Figure 11. A) Visible near infrared (VNIR) image displaying RGB true color composite- bands corresponding to wavelengths of 640,550 , and $460 \mathrm{~nm}$, location of hyperspectral scans 1, 2, and 3 are shown B) False color composite image showing SWIR RGB bands corresponding to 2378, 2334, and $2146 \mathrm{~nm}$ showing full extent of study area registered to surface mesh. Interpretation of dolomitization and bioherm geometry are denoted.

Figure 12. False color and classified imagery showing two rudist bioherms: A) False color composite RGB bands at wavelengths of 2378, 2334, and $2146 \mathrm{~nm}$; B) SAM classification using laboratory spectra of whole rock samples collected in the area. Two toucasid bioherms are outlined with dashed line and labeled TB. Tops of mounds contain dolomitized biomolds. Interreef facies (labeled IR) are also dolomitic. Chert horizons are denoted by white arrows and yellow arrow shows truncation of limestone beds. Locations of samples and photomicrographs of thin sections used for rock characterization are shown. 1) wackstone to packstone facies with rudist and coral fossil fragments (arrow); 2) packstone to grainstone, contains abundant fossil material (arrows); 3) wackstone to grainstone, photomicrograph is zoomed to fossil fragment (black arrow), presumably an ostracode, with some dolomitization (blue arrow); 4) dolomitized foraminiferal packstone, foraminifera are dissolved and in some places replaced with calcite (arrows denote a few examples); 5) wackestone with some relict fossil material (arrows); 6) wackestone showing some dedolomitization (arrows denote a few examples); 7) chert nodule with traces of silicified fossil material; 8) chert-cemented dolostone shown under crossed polars (arrows denote calcitized cores of dolomite crystals) 9) dolostone comprised of mostly euhedral to subhedral crystals; 10) dolostone showing some calcitization (arrows); 11) packstone to grainstone with some dolomitization (arrows); 12) micritic wackestone to packstone containing fossil material (black arrow) some of which appears to have undergone compression (blue arrow).

Legend denotes abundance of calcite, dolomite, and chert estimated from petrography. ${ }^{*}$ No thin section was obtained for fossiliferous wackstone. C) Oblique (southeast looking) view of rudist bioherm. Erosional profile as well as classification of surface composition facilitates characterization of rudist bioherm. 
Figure 13. Continuum removed spectra of backreef facies, showing band located at $2334 \mathrm{~nm}$, low values correspond to greater absorption at this wavelength, which corresponds to higher calcite content. Image is enlarged where carbonate nodules are observed due to their erosional profile; their location is outlined.

Figure 14. TLS-derived surface mesh texturized with: (A) visible near infrared (approximate true color) image showing bands corresponding to wavelengths of 640,550, and $460 \mathrm{~nm}$; (B) SAM classification using endmembers which were prepared from mixtures of known composition. Legend shows colors used for classification as well as relative abundances of endmember materials throughout the image. Rudist bioherms are composed of mostly calcite and minor amounts of nodular chert. The tops of bioherms as well as interreef facies are dolomitized. Backreef facies whithin scan 3 (towards the left portion of the image) contain less extensive dolomitization than bioherms and interreef facies. C) SAM classification performed using image extracted endmembers and D) Interpretation of facies seen at Lake Georgetown Spillway

\section{Discussion}

Compositional mapping of the Edwards limestone reveals the spatial distribution of carbonate minerals as well as chert concretions. This work sought to collect endmembers by preparing mixtures of known composition in the laboratory setting and applying them to classifications at outcrop scale. Endmember compositions were determined using a stepwise approach, with intervals corresponding to abundances of 20-25\%, whereas a continuous approach would account for abundances which may fall between the discrete quantities which were used. Since scans were collected throughout the day, differences in illumination occurred, not only between scans but also within one scene as cloud cover conditions were changing while the sensor moved from right to left. Accuracy of classification can be deemed substantial due to the range of kappa values between 0.6917 and 0.8910 (Landis and Koch, 1977). 
Information was extracted from classified imagery as well as petrographic analysis for interpretation of the progression of diagenetic events. Cementation, dolomitization, silicification, compaction, and de-dolomitization are prevalent in the study area. Dolomitization of limestones has been associated with increased porosity in studies such as Bissell and Chilingar (1958), Murray (1960), Murray (1930), and Weyl (1960). Murray (1960) proposes that in the case of "sucrosic" dolostones, the growth of randomly oriented euhedral dolomite crystals accompanied by dissolution of calcite which has not been replaced can increase porosity development.

Rudist bioherm geometry can be observed in the TLS-derived surface mesh texturized with hyperspectral data. The core of both mounds consists of fossiliferous packstones overlain by dolomitized wackestones. More micritic facies at the base of bioherms were not dolomitized extensively due to lack of permeability to fluid flow, whereas overlying packstone to grainstone facies have greater extent of dolomitization. The dolomite observed in this area is likely to be massive dolomite described by Fisher and Rodda (1969). Extensive dolomitization is mapped in the study area and is associated with increased porosity where there is no chert cementation. Caprinid mounds dip to the north, providing accommodation space for overlying meter scale toucasid mounds. Sucrosic dolostones lacking original shell material and nodular limestones suggest a restricted evaporitic microtidal environment (Sullivan and Zahm, 2005).

Chert was likely emplaced after dolomitization; this is confirmed by petrographic study (Figure $7 \mathrm{E}$ ). The presence of chert nodules and megaquartz crystals suggests a sabkha environment and/or the presence of siliceous biota. Chert nodules range in size and are frequently found in association with dolomite throughout the Edwards Formation (Pittman, 1959). In the case of chert-cemented dolostone, if dolomite crystals are 
enveloped in chert, dolomitization preceded chert, which has replaced host limestone (Chafetz and Zhang, 1998; Powers, 1962). In the Edwards Formation, silica is known to replace host limestone post-dolomitization but pre-lithification (Pittman, 1959). Carbonate nodules were imaged in the northernmost portion of the scan, and evidence of anhydrite was found by Chen et al. (2016) in authigenic quartz crystals in nearby areas. Evaporites are known in some cases to be silicified or calcitized, forming nodules (Ulmer-Scholle and Scholle, 1994).

Based on facies distribution interpreted from hyperspectral imagery and petrographic study, it is possible to infer changes in local sea level (Figure 15). Rudists are known to exist at a wide range of depths but must have been submerged under at least a few meters of water, developing at the shelf edge (Fisher and Rodda, 1969; Sanders, 1998). Falling sea level would have led to evaporative conditions and seepage reflux dolomitization, which involves an increase in $\mathrm{Mg} / \mathrm{Ca}$ ratio associated with precipitation of evaporates, presumably from the nearby Kirschberg Lagoon. Interreef facies consist of mostly debris grainstones and packstones which are porous and likely permeable to dolomitizing fluids. Extensive dolomitization of interreef facies between the two rudist buildups likely required further decrease in sea level to facilitate evaporative conditions as well as transport of dolomitizing fluids to topographically lower areas. Overlying rocks contain foraminifera but no signs of rudist shells or fragments. This leads to the conclusion of increased local sea level when these facies were deposited.

Figure 15. Simplified diagram of paragenesis observed at the southeastern wall of Lake Georgetown Spillway. (A) Rudist bioherms form during a time of relatively high local sea level. (B) As local sea level falls, evaporation is increased, producing dolomitizing fluids which permeate into carbonate sediments (Tucker and Wright, 1990). (C) Sea level continues to decrease, and dolomitized tops of the bioherms are exposed. It 
is likely that during this time, interreef debris is dolomitized. (D) During subsequent rise of sea level, foraminifera are abundant and are the main fossil constituents of overlying deposits. Silicification likely occurred after dolomitization and in some cases after subsequent dedolomitization (inferred from petrographic study).

Dedolomitization, the process of dolomite dissolution and calcitization due to presence of fluids with high $\mathrm{Ca}^{2+} / \mathrm{Mg}^{2+}$ ratio, (Back et al., 1983) occurs in the Edwards formation (Deike, 1990). It can be observed in most samples collected in the field area, and it is notable that porosity is increased where dolomite rhombs are partially or completely dissolved (Figure 7B and C). This porosity is destroyed where chert cementation occurred (shown in Figure 7E).

\section{Conclusion}

Close range ground based remote sensing surveys are useful for augmentation of outcrop studies paired with traditional outcrop observation and petrographic analysis. Although hyperspectral imaging on its own is a valuable tool for outcrop characterization, when corrected with spatially accurate TLS data, distortion which is inherent to the two dimensional hyperspectral imagery is reduced, providing spatially accurate and spectrally rich datasets for rapid and precise geological interpretation. With some knowledge of the area and composition of endmember lithologies, this method is a powerful tool for mapping distribution and quantifying relative abundances of minerals in areas which may not be physically accessible, such as a vertical cliff face. Study of exposed Edwards Formation in the Lake Georgetown Spillway reveals information about the development of rudist buildups and the progression of diagenetic events leading to mineral alteration. The distribution of porous dolomitized rocks mapped in the vertical rock exposures of the Lake Georgetown Spillway suggests 
possible pathways of fluid-flow in the host rock. Understanding the fluid-flow through sedimentary units could be useful for the study of natural resources such as groundwater and hydrocarbons in the subsurface providing critical information for aquifer and reservoir analogues.

\section{Acknowledgements}

Hyperspectral cameras used in this study were purchased by National Science Foundation Award Number 1256202. We would like to express gratitude to Dr. Juan Carlos Silva Tamayo for helpful comments in preparation of this work, Dr. Alex Robinson, Dr. Adry Bissada and Dr. Joel Saylor for use of their equipment in the field and laboratory, and Dr. Charlotte Sullivan, Kivanc Biber, Lei Sun, Ismail Abir, and Daisy Huang for help with field work. Two anonymous reviewers are thanked for helpful comments in preparation of this work.

\section{References}

Back, W. et al., 1983. Process and rate of dedolomitization: Mass transfer and $14 \mathrm{C}$ dating in a regional carbonate aquifer. GSA Bulletin, 94: 1415-1429.

Baissa, R., Labbassi, K., Launeau, P., Gaudin, A., Ouajhain, B., 2011. Using HySpex SWIR$320 \mathrm{~m}$ hyperspectral data for the identification and mapping of minerals in hand specimens of carbonate rocks from the Ankloute Formation (Agadir Basin, Western Morocco). Journal of African Earth Sciences, 61(1): 1-9.

Baugh, W.M., Kruse, F.A., Atkinson Jr, W.W., 1998. Quantitative Geochemical Mapping of Ammonium Minerals in the Southern Cedar Mountains, Nevada, Using the Airborne Visible/Infrared Imaging Spectrometer (AVIRIS). Remote Sensing of Environment, 65(3): 292-308.

Bell, J.H., Bowen, B.B., Martini, B., 2010. Spectroscopy of sulfates, clays, and iron oxides in the Jurassic Navajo Sandstone, Geoscience and Remote Sensing Symposium. IEEE, Honolulu, HI, pp. 227-229.

Bellian, J.A., Beck, R., Kerans, C., 2007. Analysis of hyperspectral and lidar data: Remote optical mineralogy and fracture identification. Geosphere, 3(6): 491-500.

Bissell, H.J., Chilingar, G.V., 1958. Notes on diagenetic dolomitization. Journal of Sedimentary Research, 28(4): 490-497. 
Borgomano, J., Masse, J.P., Maskery, S.A., 2002. The lower Aptian Shuaiba carbonate outcrops in Jebel Akhdar, northern Oman: Impact on static modeling for Shuaiba petroleum reservoirs. AAPG Bulletin, 86(9): 1513-1529.

Bornaz, L., Rinaudo, F., 2004. Terrestrial laser scanner data processing, XXth ISPRS Congress Istanbul.

Bowen, B.B., Martini, B.A., Chan, M.A., Parry, W.T., 2007. Reflectance spectroscopic mapping of diagenetic heterogeneities and fluid-flow pathways in the Jurassic Navajo Sandstone. AAPG Bulletin, 91(2): 173-190.

Chafetz, H.S., Zhang, J., 1998. Authigenic euhedral quartz crystals in a Quaternary dolomite. Journal of Sedimentary Research, 68(5): 994-1000.

Chen, X., Chafetz, H.S., Andreasen, R., Lapen, T.J., 2016. Silicon isotope compositions of euhedral authigenic quartz crystals: Implications for abiotic fractionation at surface temperatures. Chemical Geology, 423: 61-73.

Clark, R.N., 1981. Water frost and ice: The near-infrared spectral reflectance 0.65-2.5 $\mu \mathrm{m}$. Journal of Geophysical Research: Solid Earth, 86(B4): 3087-3096.

Clark, R.N., 1999. Spectroscopy of Rocks and Minerals, and Principles of Spectroscopy. In: A.N. Rencz (Ed.), Manual of Remote Sensing. John Wiley and Sons, Inc, New York, pp. 3- 58.

Clark, R.N., King, T.V., 1987. Automatic continuum analysis of reflectance spectra.

Clark, R.N., Roush, T.L., 1984. Reflectance Spectroscopy: Quantitative Analysis Techniques for Remote Sensing Applications. Journal of Geophysical Research, 89(B7): 6329-6340.

Clark, R.N. et al., 2007. USGS digital spectral library splib06a. In: USGS (Ed.). Digital Data Series 231.

Collins, E.W., 2005. Geologic map of the west half of the Taylor, Texas, 30 X 60 minute quadrangle: central Texas urban corridor, encompassing Round Rock, Georgetown, Salado, Briggs, Liberty Hill, and Leander. University of Texas at Austin, Bureau of Economic Geology, Austin, TX.

Damman, A.J., 2011. A Comparison of the Cretaceous (Albian) Edwards Limestone Bioherms of Central Texas with the Holocene Coral Reefs of Bermuda, Baylor University.

Deike, R.G., 1990. Dolomite dissolution rates and possible Holocene dedolomitization of water-bearing units in the Edwards aquifer, south-central Texas. Journal of Hydrology, 112(3-4): 335-373.

Fisher, W.L., Rodda, P.U., 1969. Edwards Formation (Lower Cretaceous), Texas: Dolomitization in a Carbonate Platform System. AAPG Bulletin, 53(1): 55-72.

Fritz, D.A. et al., 2000. New Exploration Concepts for the Edwards and Sligo Margins, Cretaceous of Onshore Texas. AAPG Bulletin, 84(7): 905-922.

Gaffey, S.J., 1987. Spectral reflectance of carbonate minerals in the visible and near infrared (0.35-2.55 um): Anhydrous carbonate minerals. Journal of Geophysical Research, 92(B2): 1429-1440.

Gili, E., Masse, J.P., Skelton, P.W., 1995. Rudists as gregarious sediment-dwellers, not reef-builders, on Cretaceous carbonate platforms. Palaeogeography, Palaeoclimatology, Palaeoecology, 118: 245-267.

Green, A.A., Berman, M., Switzer, P., Craig, M.D., 1988. A transformation for ordering multispectral data in terms of image quality with implications for noise removal. Geoscience and Remote Sensing, IEEE Transactions on, 26(1): 65-74. 
Greenberger, R.N. et al., 2015. Hydrothermal alteration and diagenesis of terrestrial lacustrine pillow basalts: Coordination of hyperspectral imaging with laboratory measurements. Geochimica et Cosmochimica Acta, 171: 174-200.

Hecker, C., van der Meijde, M., van der Werff, H., van der Meer, F.D., 2008. Assessing the Influence of Reference Spectra on Synthetic SAM Classification Results. Geoscience and Remote Sensing, IEEE Transactions on, 46(12): 4162-4172.

Huang, F., Klette, R., Scheibe, K., 2008. Panoramic imaging : sensor-line cameras and laser range-finders. John Wiley \& Sons, Chichester, West Sussex, UK.

Johnson, S., Schnidel, G., Hoyt, J., 2009. Water quality trends analysis of the San Antonio Segment, Balcones fault zone Edwards Aquifer, Texas, Edwards Aquifer Authority, San Antonio, TX.

Kaab, A., 2005. Remote Sensing of Mountain Glaciers and Permafrost Creep. Geographisches Institut der Universität Zürich, Zurich, 264 pp.

Kazhdan, M., Bolitho, M., Hoppe, H., 2006. Poisson Surface Reconstruction. In: K. Polthier, A. Sheffer (Eds.), Eurographics Symposium on Geometry Processing, Sardinia, Italy.

Keskin, G., Can, C., 1986. Upper cretaceous carbonate reservoirs of the Raman Field, Southeast Turkey. Carbonates and Evaporites, 1(1): 25-43.

Kruse, F.A. et al., 1993. The spectral image processing system (SIPS)-interactive visualization and analysis of imaging spectrometer data. Remote Sensing of Environment, 44(2-3): 145-163.

Kurz, T.H., Buckley, S.J., Howell, J.A., 2013. Close-range hyperspectral imaging for geological field studies: workflow and methods. International Journal of Remote Sensing, 34(5): 1798-1822.

Kurz, T.H. et al., 2012. Hyperspectral image analysis of different carbonate lithologies (limestone, karst and hydrothermal dolomites): the Pozalagua Quarry case study (Cantabria, North-west Spain). Sedimentology, 59(2): 623-645.

Lai, P., Samson, C., Bose, P., 2014. Surface roughness of rock faces through the curvature of triangulated meshes. Computers \& Geosciences, 70: 229-237.

Landis, J.R., Koch, G.G., 1977. The Measurement of Observer Agreement for Categorical Data. Biometrics, 33(1): 159-174.

Maclay, R.W., Small, T.A., 1986. Carbonate Geology and Hydrology of the Edwards Aquifer in the San Antonio Area, Texas. 296, Austin, TX.

McCord, T.B. et al., 1981. Moon: Near-infrared spectral reflectance, A first good look. Journal of Geophysical Research: Solid Earth, 86(B11): 10883-10892.

Meagher, D.J.R., 1980. Octree Encoding: a New Technique for the Representation, Manipulation and Display of Arbitrary 3-D Objects by Computer.

Minisini, D., Wang, M., Bergman, S.C., Aiken, C., 2014. Geological data extraction from lidar 3-D photorealistic models: A case study in an organic-rich mudstone, Eagle Ford Formation, Texas. Geosphere, 10(3): 610-626.

Moredock, D.E., Van Ciclen, D.C., 1964. Regional Variation of Hydrocarbons in the Edwards Limestone (Cretaceous) of South Texas, Gulf Coast Association of Geological Societies. The Gulf Coast Association of Geological Societies, pp. 253270.

Mukherjee, D., Heggy, E., Khan, S.D., 2010. Geoelectrical constraints on radar probing of shallow water-saturated zones within karstified carbonates in semi-arid environments. Journal of Applied Geophysics, 70(3): 181-191. 
Mukherjee, D., Khan, S.D., Sullivan, C., 2012. Upper Albian rudist buildups of the Edwards Formation in central Texas: A GPR-assisted reservoir analog study. Sedimentary Geology: 71-81.

Murphy, R.J., 2015. Mapping clay minerals in an open-pit mine using hyperspectral and LiDAR data. European Journal of Remote Sensing: 511-526.

Murray, A.N., 1930. Limestone oil reservoirs of the northeastern United States and of Ontario, Canada. Economic Geology, 25(5): 452-469.

Murray, R.C., 1960. Origin of porosity in carbonate rocks. Journal of Sedimentary Research, 30(1): 59-84.

Nelson, H.F., 1973. The Edwards Reef Complex And Associated Sedimentation In Central Texas, Geological Society of America. Bureau of Economic Geology, Dallas, TX, pp. 34.

Okyay, U., Khan, S.D., 2016. Remote detection of fluid-related diagenetic mineralogical variations in the Wingate Sandstone at different spatial and spectral resolutions. International Journal of Applied Earth Observation and Geoinformation, 44: 7087.

Palache, C., 1937. The minerals of Franklin and Sterling Hill Sussex County, New Jersey, United States Department of the Interior, Washington, D. C.

Pittman, J.S., 1959. Silica in Edwards Limestone, Travis County, Texas. Special Publications of SEPM, 7: 121-134.

Powers, R.W., 1962. Arabian Upper Jurassic Carbonate Reservoir Rocks, Classification of Carbonate Rocks - A symposium, pp. 122-192.

Pringle, J.K., Howell, J.A., Hodgetts, D., Westerman, A.R., Hodgson, D.M., 2006. Virtual outcrop models of petroleum reservoir analogues: a review of the current stateof-the-art. First Break, 24(3): 33-42.

Roach, L.H. et al., 2006. Finding mineralogically interesting targets for exploration from spatially coarse visible and near IR spectra. Earth and Planetary Science Letters, 252(1-2): 201-214.

Rose, P.R., 1974. Edwards Group, Surface and Subsurface, Central Texas. Houston Geological Society Bulletin, 17(1): 3-3.

Sadooni, F.N., 2005. The nature and origin of Upper Cretaceous basin-margin rudist buildups of the Mesopotamian Basin, southern Iraq, with consideration of possible hydrocarbon stratigraphic entrapment. Cretaceous Research, 26(2): 213-224.

Sanders, D., 1998. Upper Cretaceous rudist formations. Geol. Paläont. Mitt. Innsbruck, 23: 37-59.

Schneider, D., 2009. Calibration of a Riegl LMS-Z420i based on a multi-station adjustment and a geometric model with additional parameters. Int. Arch. Photogramm. Remote Sens. Spat. Inf, 38: 177-182.

Smith, G.M., Milton, E.J., 1999. The use of the empirical line method to calibrate remotely sensed data to reflectance. International Journal of Remote Sensing, 20(13): 2653-2662.

Snyder, C.J., Khan, S.D., Bhattacharya, J.P., Glennie, C., Seepersad, D., 2016. Thin-bedded reservoir analogs in an ancient delta using terrestrial laser scanner and highresolution ground-based hyperspectral cameras. Sedimentary Geology, 342: 154-164. 
Sullivan, C., Zahm, L., 2005. Field trip stop 8: Edwards Banks, Lake Georgetown Spillway, Williamson County. In: H.F. Filkorn, C.C. Johnson, A. Molineux, R.W. Scott (Eds.), Seventh international congress on rudists. SEPM, Austin, TX.

Tangier Smith, W.S., Siebenthal, C.E., 1906. Description of the Joplin District, USGS.

Tucker, M., Wright, P., 1990. Carbonate Sedimentology. Blackwell Scientific Publications Oxford, 314-400 pp.

Ulmer-Scholle, D.S., Scholle, P.A., 1994. Replacement of evaporites within the Permian Park City Formation, Bighorn Basin, Wyoming, USA. Sedimentology, 41(6): 1203.

van der Meer, F., 1994. Sequential indicator conditional simulation and indicator kriging applied to discrimination of dolomitization in GER 63-channel imaging spectrometer data Nonrenewable Resources, 3: 146-164.

Van der Meer, F., 1995. Spectral Reflectance of Carbonate Mineral Mixtures and Bidirectional Reflectance Theory: Quantitative Analysis techniques for Application in Remote Sensing. Remote Sensing Reviews, 13: 67-94.

Vega, F.J., Lawton, T.F., 2011. Upper Jurassic (Lower Kimmeridgian-Olvido) carbonate strata from the La Popa Basin diapirs, NE Mexico. Boletín de la Sociedad Geológica Mexicana, 63(2): 313-321.

Vosselman, G., Maas, H.-G., 2010. Airborne and Terrestrial Laser Scanning. Whittles Publishing, Scotland, UK.

Welch, C.L., 2001. Petrography and Geochemistry of Dolomites in the Lower Cretaceous Edwards Formation, Taylor County, Texas, Texas Tech University, 109 pp.

Weyl, P., 1960. Porosity through dolomitization: conservation of mass requirements. Journal of Sedimentary Petrology, 30(1): 85-90. 


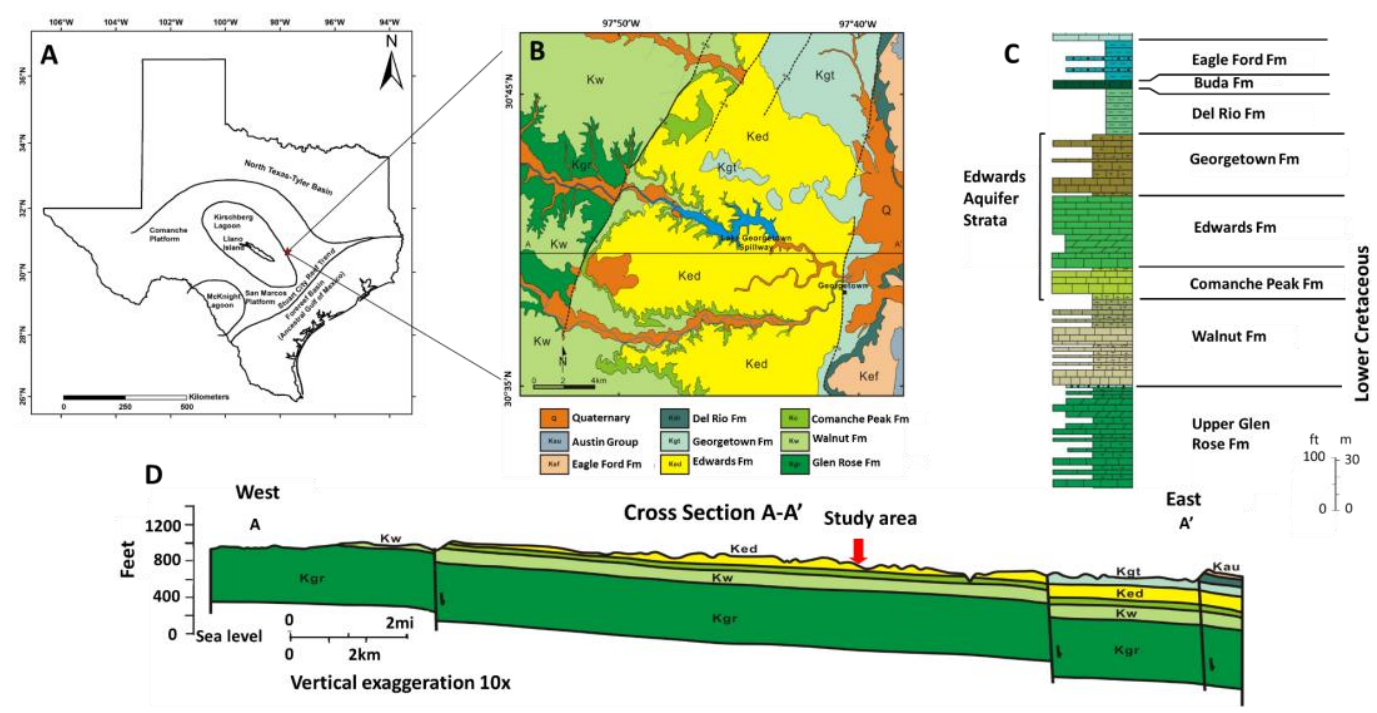

Figure 1 


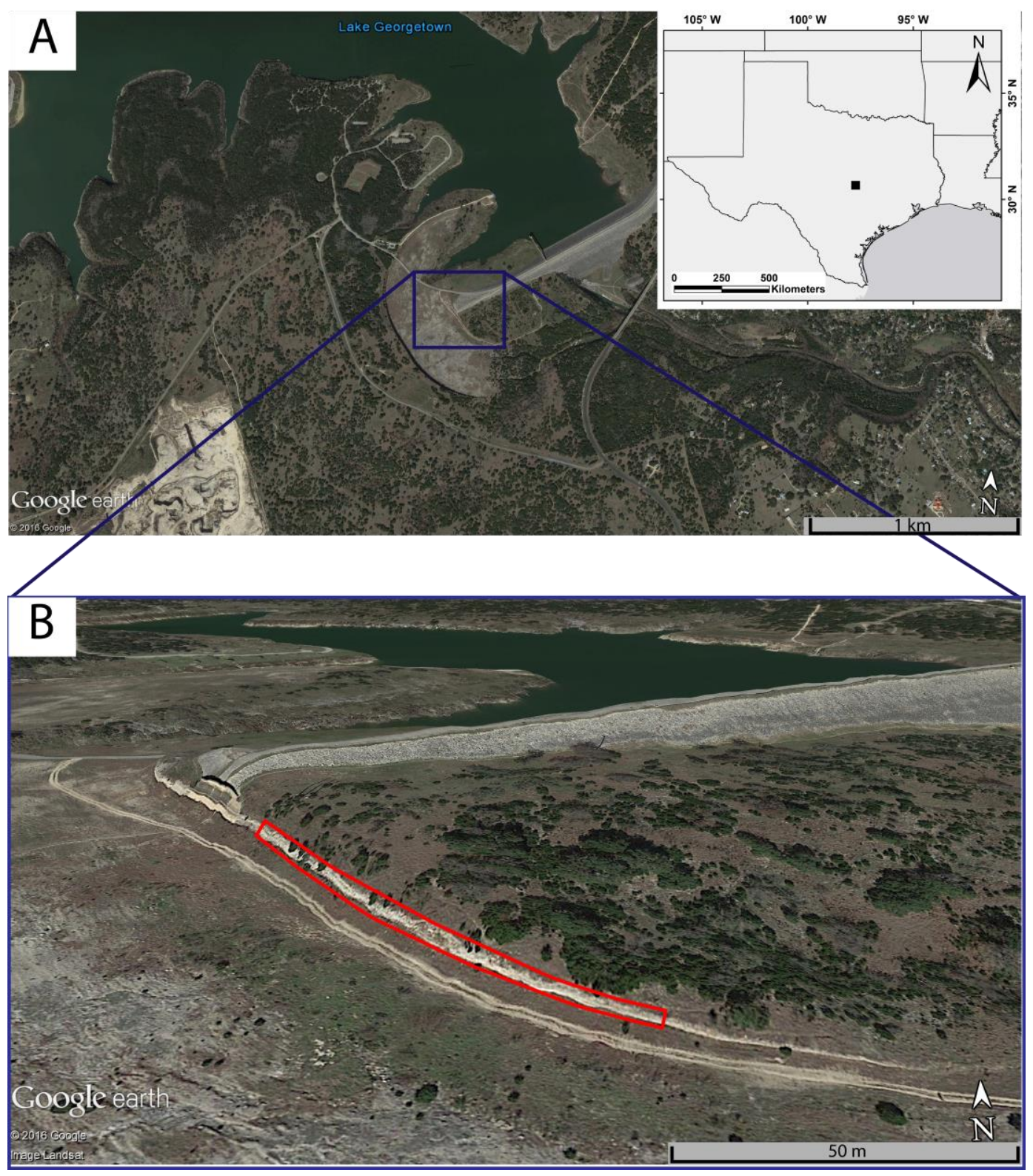

Figure 2 


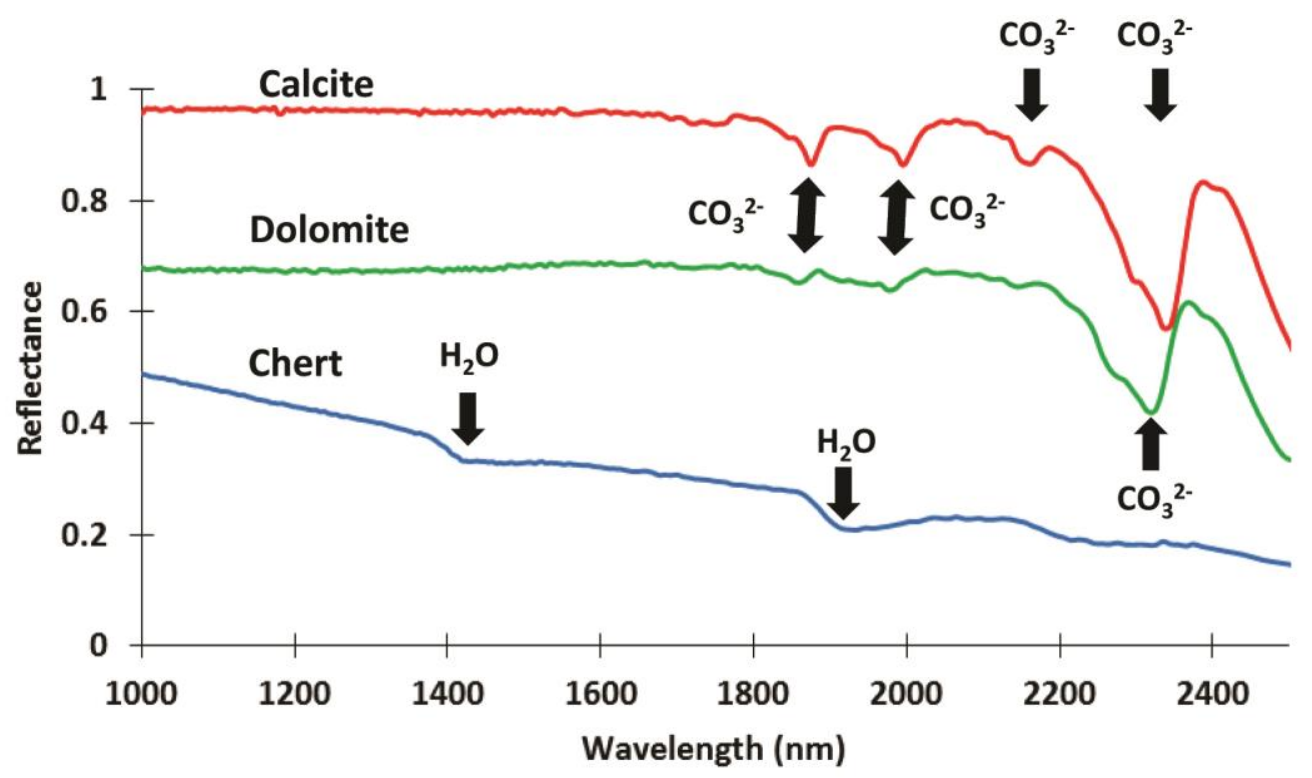

Figure 3 


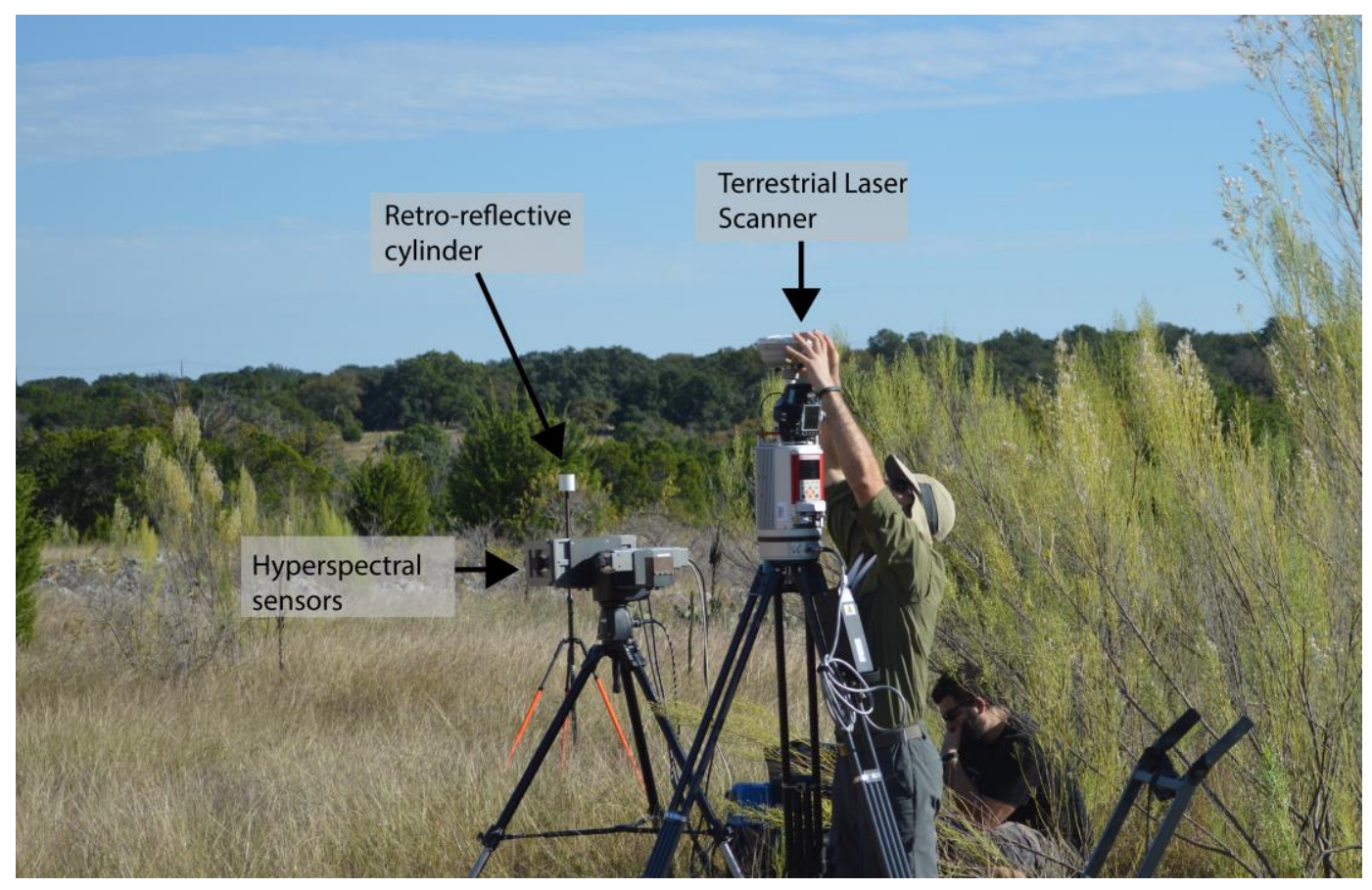

Figure 4 
A

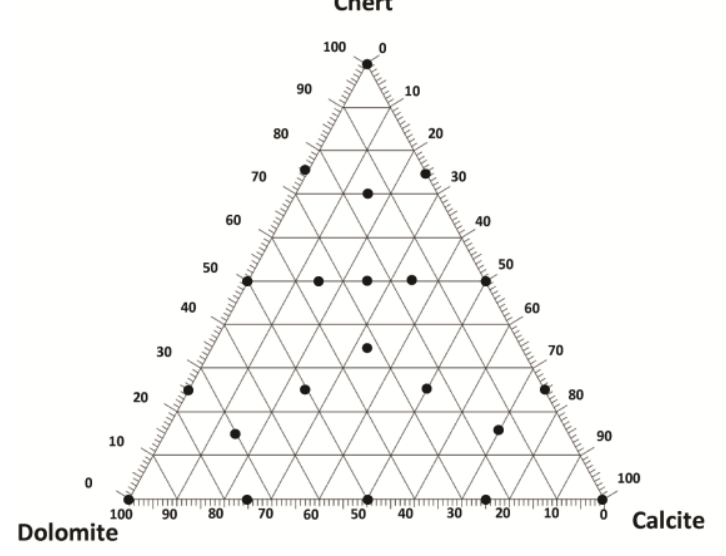

B

\begin{tabular}{|rrrr}
\hline $\begin{array}{r}\text { Sample } \\
\text { number }\end{array}$ & $\begin{array}{r}\text { Calcite } \\
\text { percentage }\end{array}$ & $\begin{array}{r}\text { Dolomite } \\
\text { percentage }\end{array}$ & $\begin{array}{r}\text { Chert } \\
\text { percentage }\end{array}$ \\
\hline $\mathbf{1}$ & 100 & 0 & 0 \\
$\mathbf{2}$ & 0 & 100 & 0 \\
\hline $\mathbf{3}$ & 0 & 0 & 100 \\
\hline $\mathbf{4}$ & 0 & 25 & 75 \\
\hline $\mathbf{5}$ & 0 & 50 & 50 \\
\hline $\mathbf{6}$ & 0 & 75 & 25 \\
\hline $\mathbf{7}$ & 25 & 75 & 0 \\
\hline $\mathbf{8}$ & 50 & 50 & 0 \\
\hline $\mathbf{9}$ & 75 & 25 & 0 \\
\hline $\mathbf{1 0}$ & 50 & 0 & 50 \\
\hline $\mathbf{1 1}$ & 25 & 0 & 75 \\
\hline $\mathbf{1 2}$ & 15 & 15 & 70 \\
\hline $\mathbf{1 3}$ & 15 & 35 & 50 \\
\hline $\mathbf{1 4}$ & 25 & 25 & 50 \\
\hline $\mathbf{1 5}$ & 35 & 15 & 50 \\
\hline $\mathbf{1 6}$ & 33 & 33 & 33 \\
\hline $\mathbf{1 7}$ & 25 & 50 & 25 \\
\hline $\mathbf{1 8}$ & 50 & 25 & 25 \\
\hline $\mathbf{1 9}$ & 15 & 70 & 15 \\
\hline $\mathbf{2 0}$ & 70 & 15 & 15 \\
\hline
\end{tabular}

Figure 5 


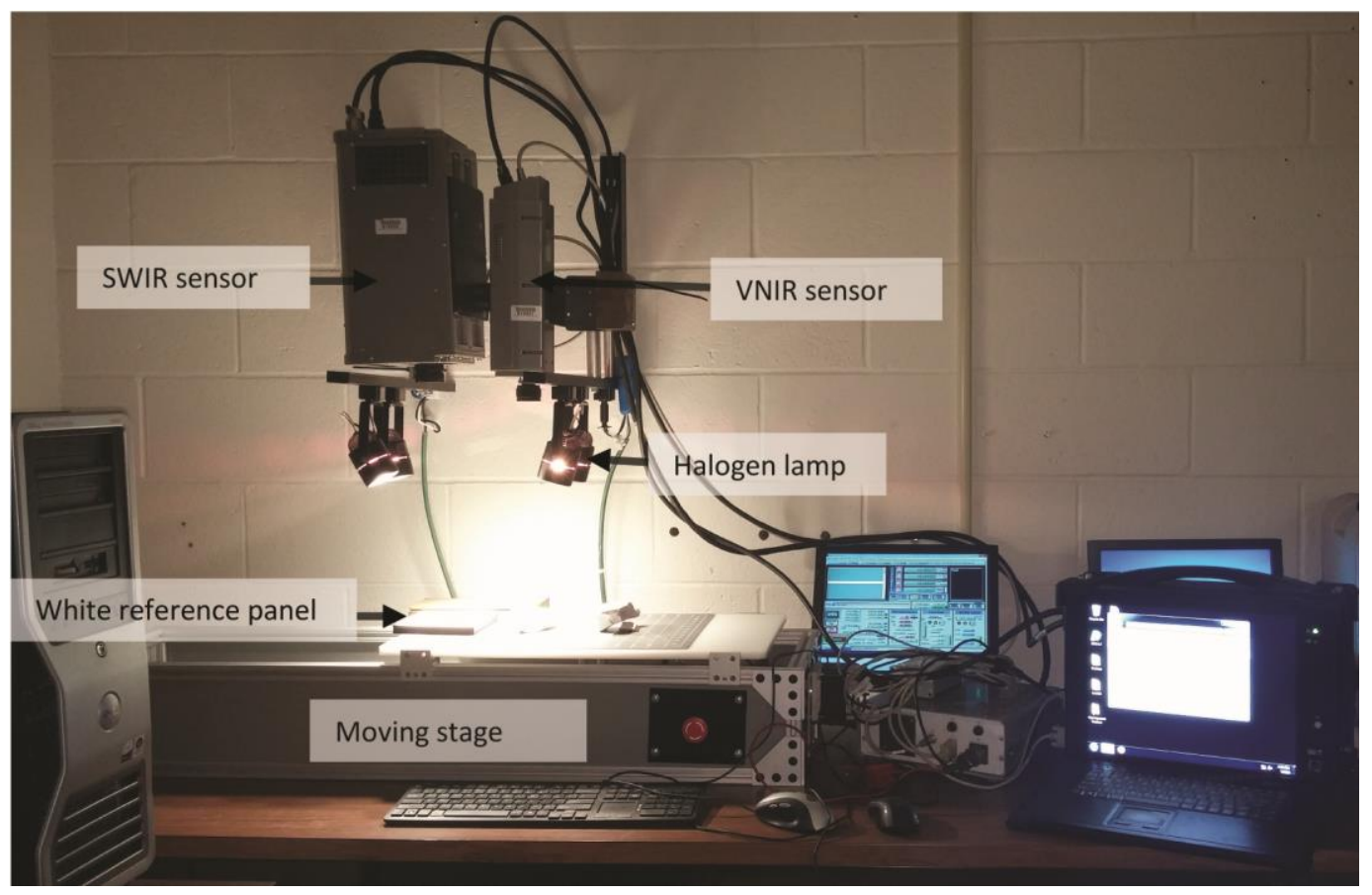

Figure 6 

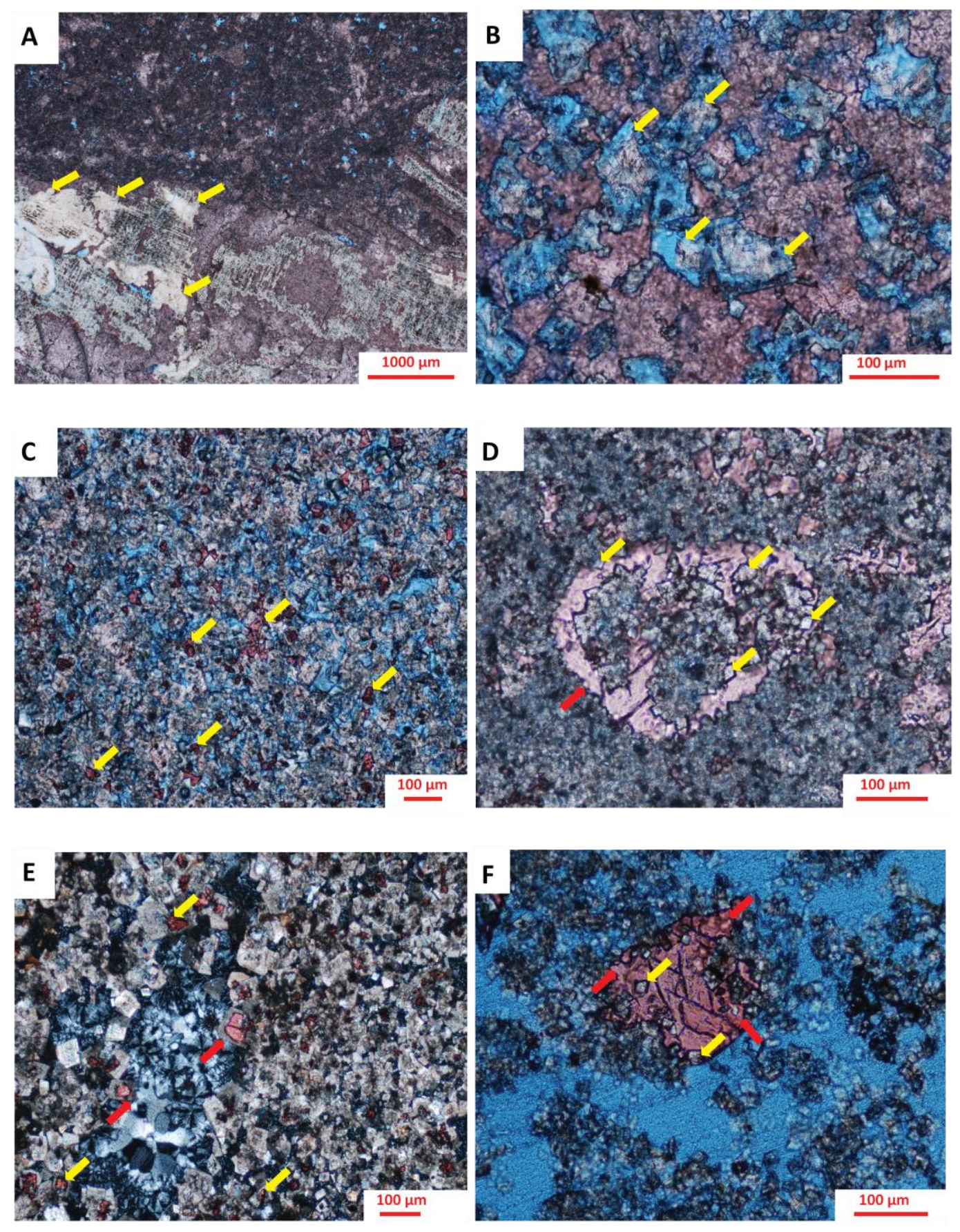

Figure 7 
A

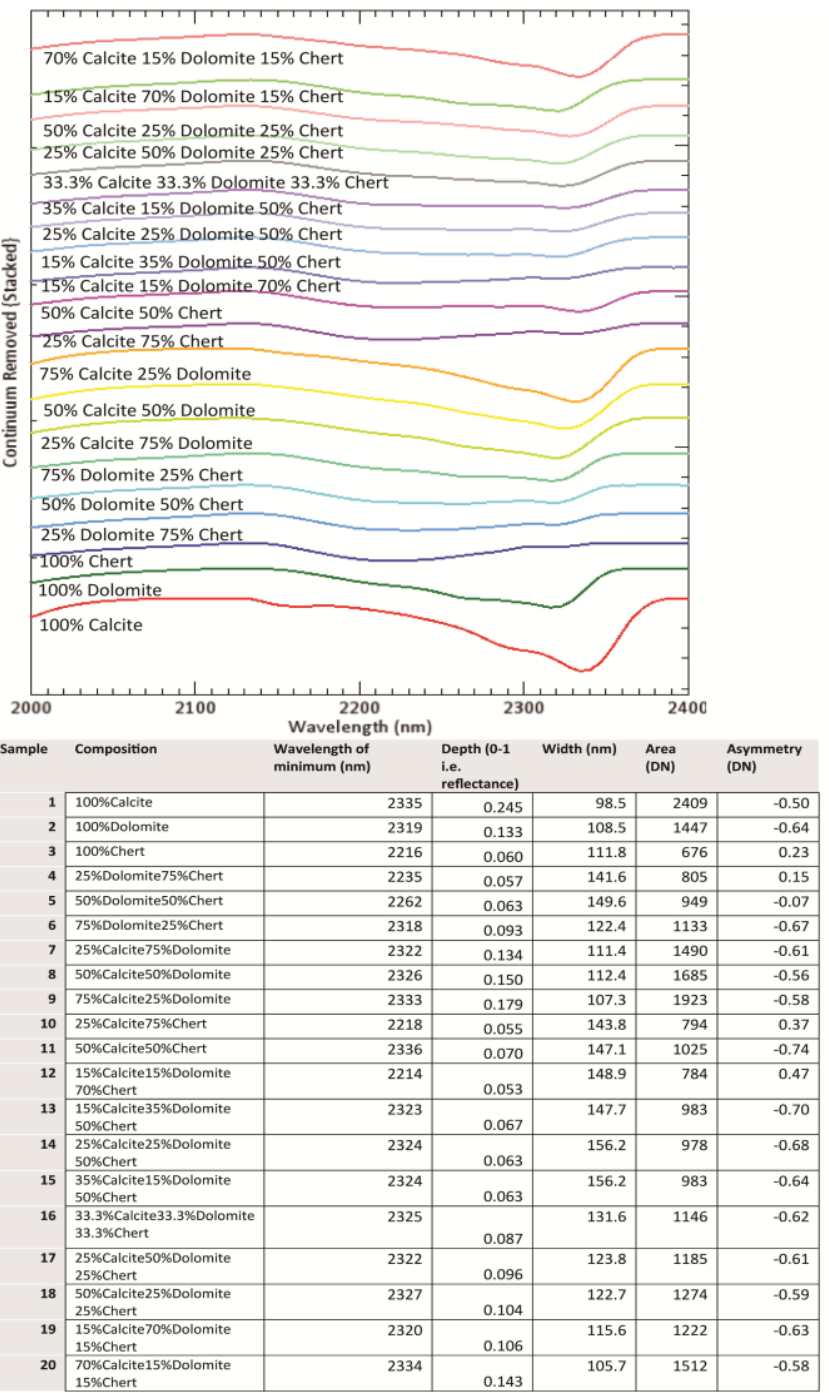

c

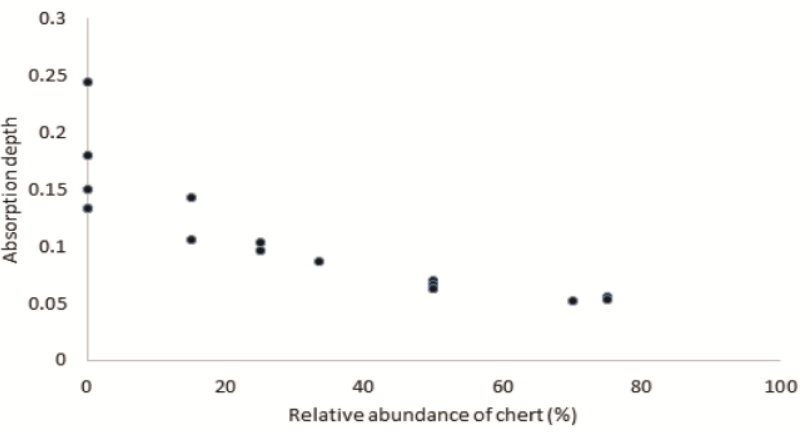

Figure 8 


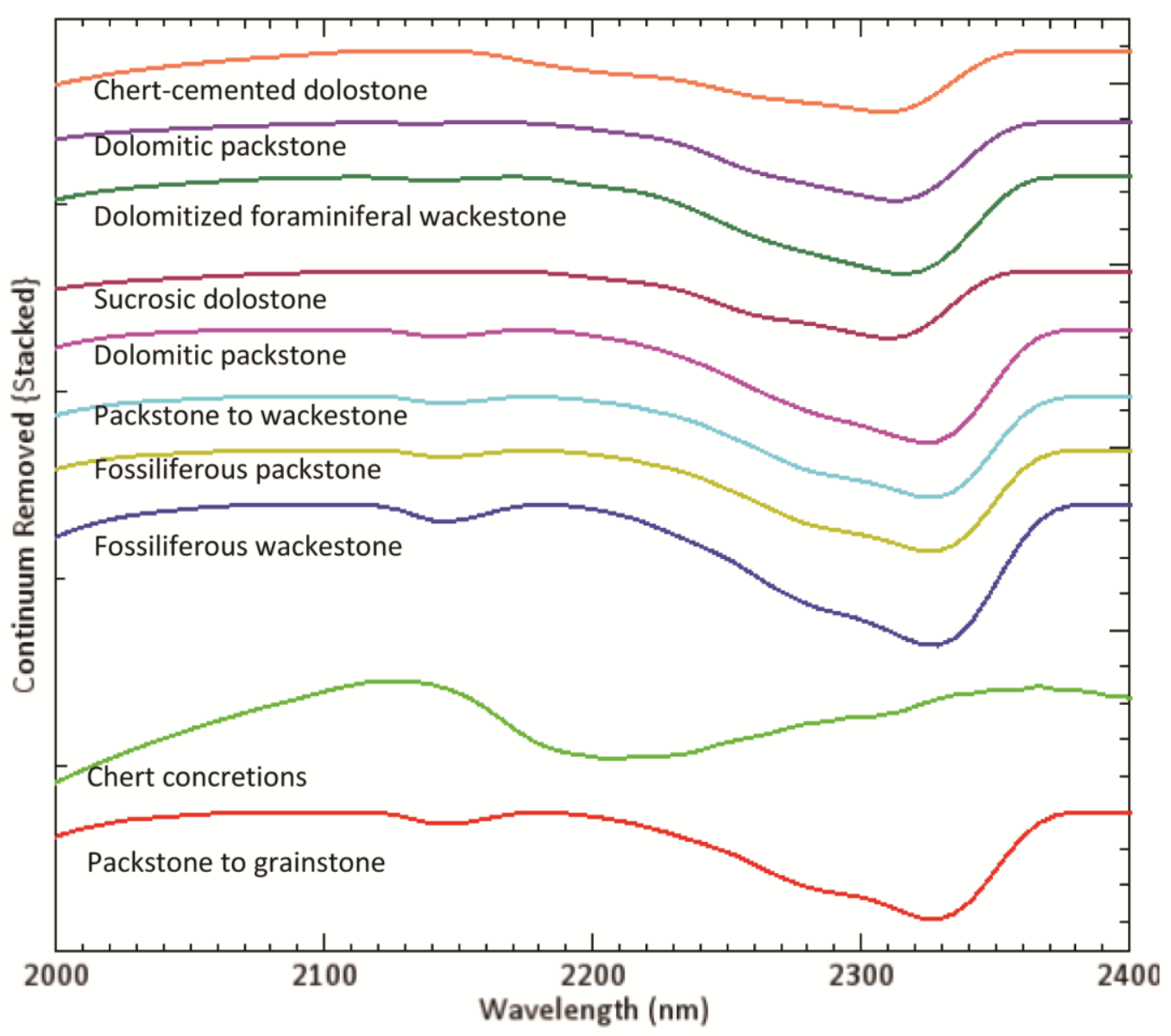

Figure 9 


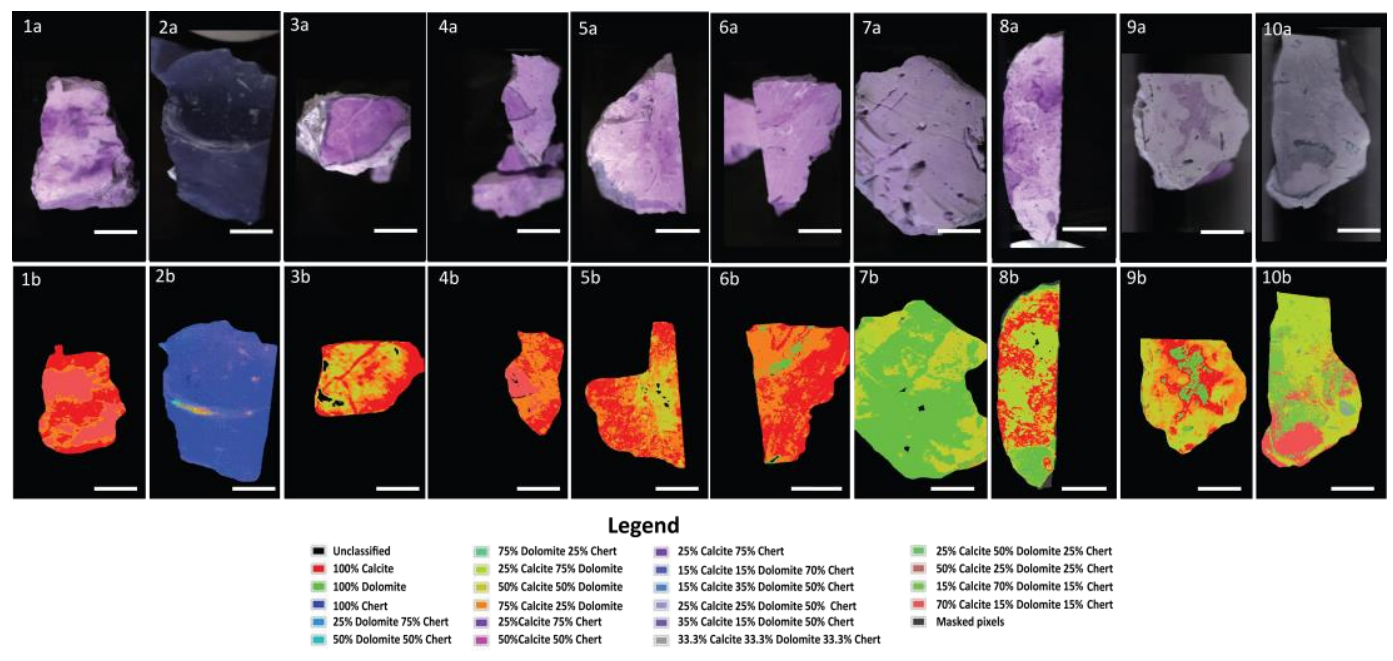

Figure 10 

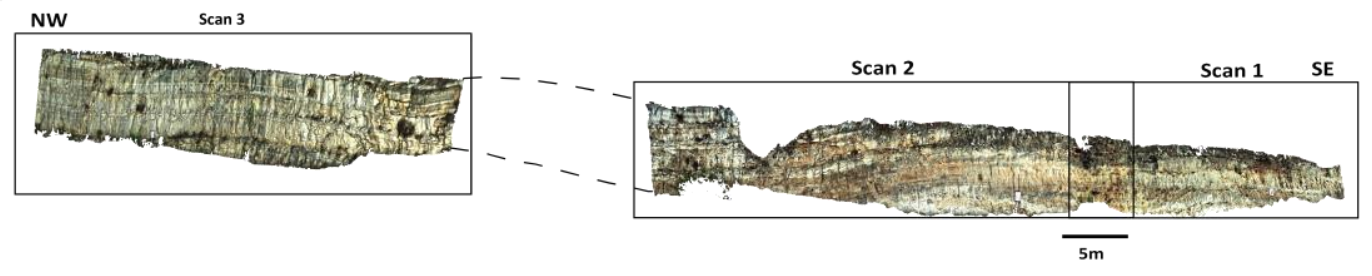

B

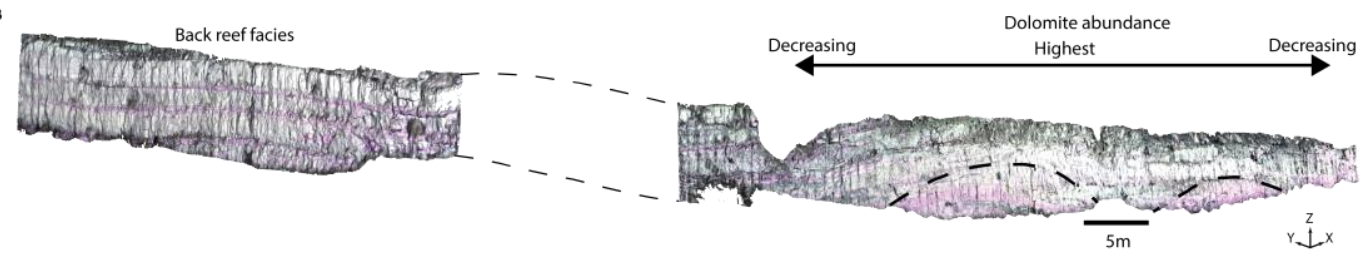

Figure 11 
A
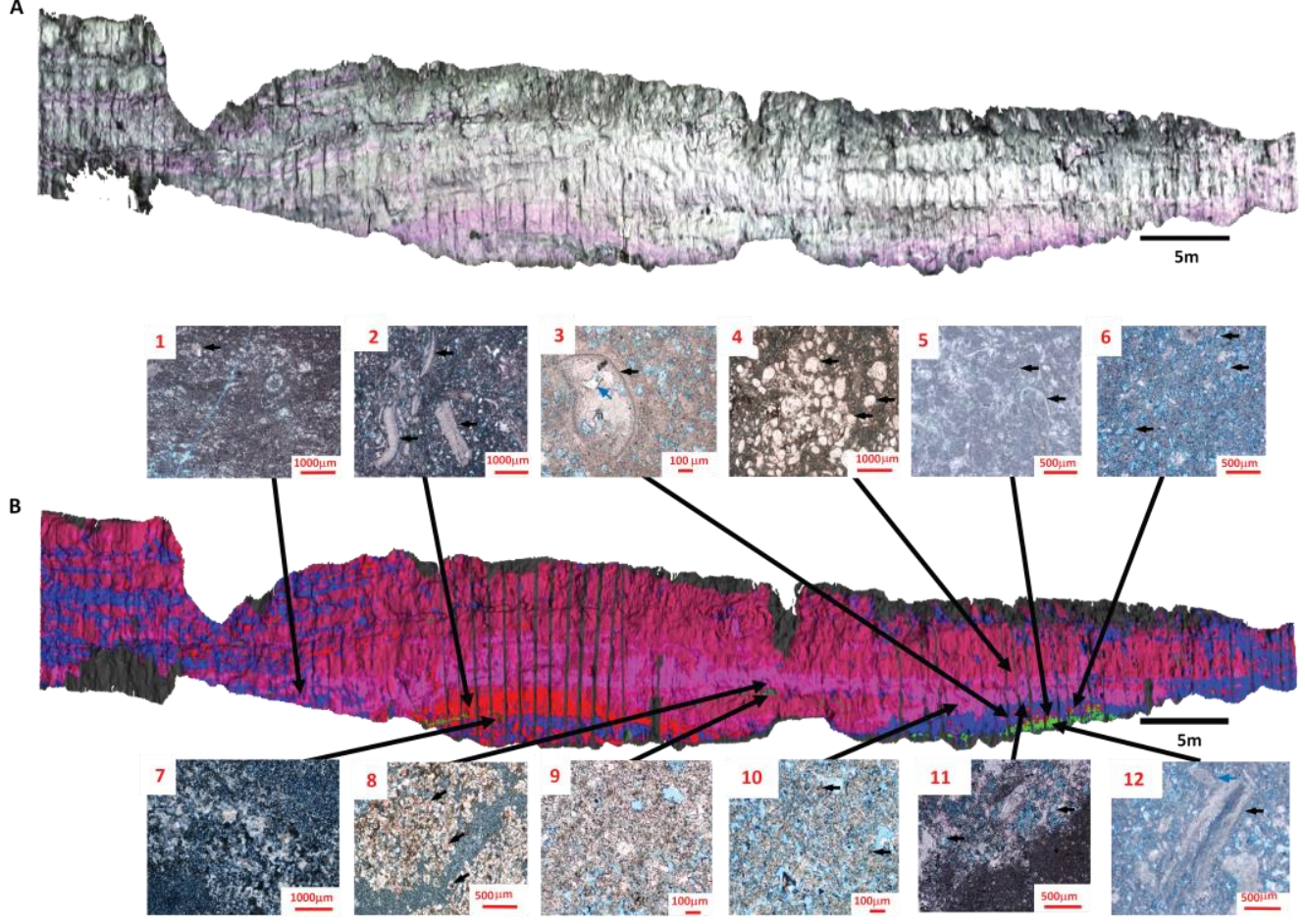

c

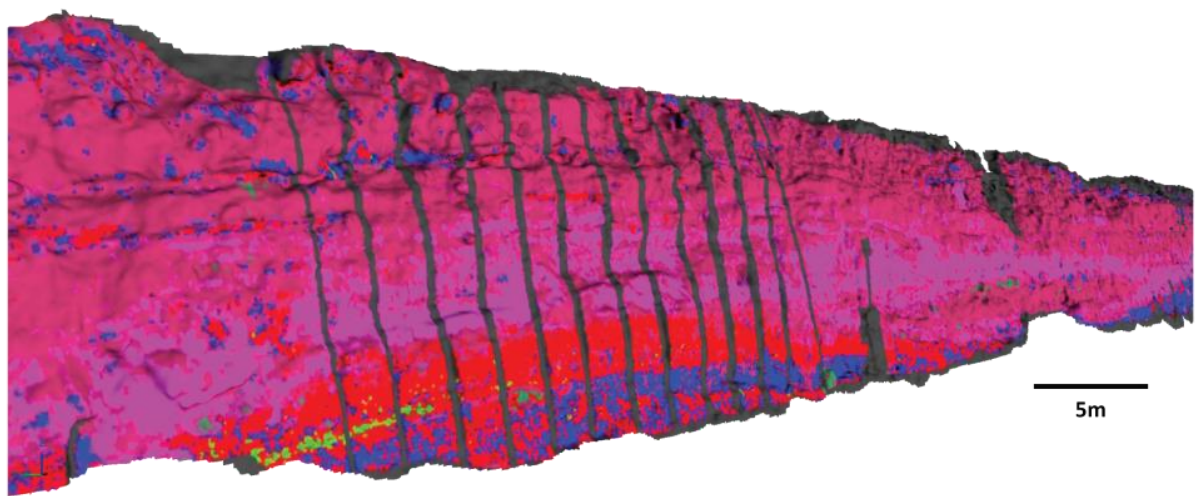

\section{Legend}
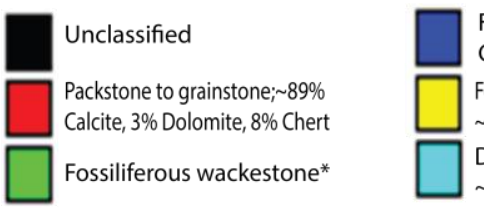

Fossiliferous packstone; 78\%

Calcite, 22\% Dolomite

Fossiliferous packstone to wackestone

$\sim 71 \%$ Calcite, 29\% Dolomite

Dolomitic packstone;

65\% Calcite; 35\% Dolomite

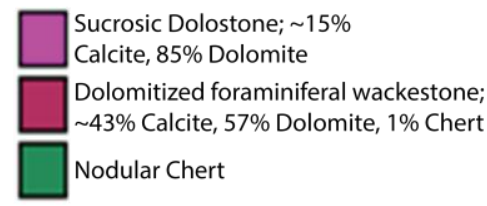

Figure 12 


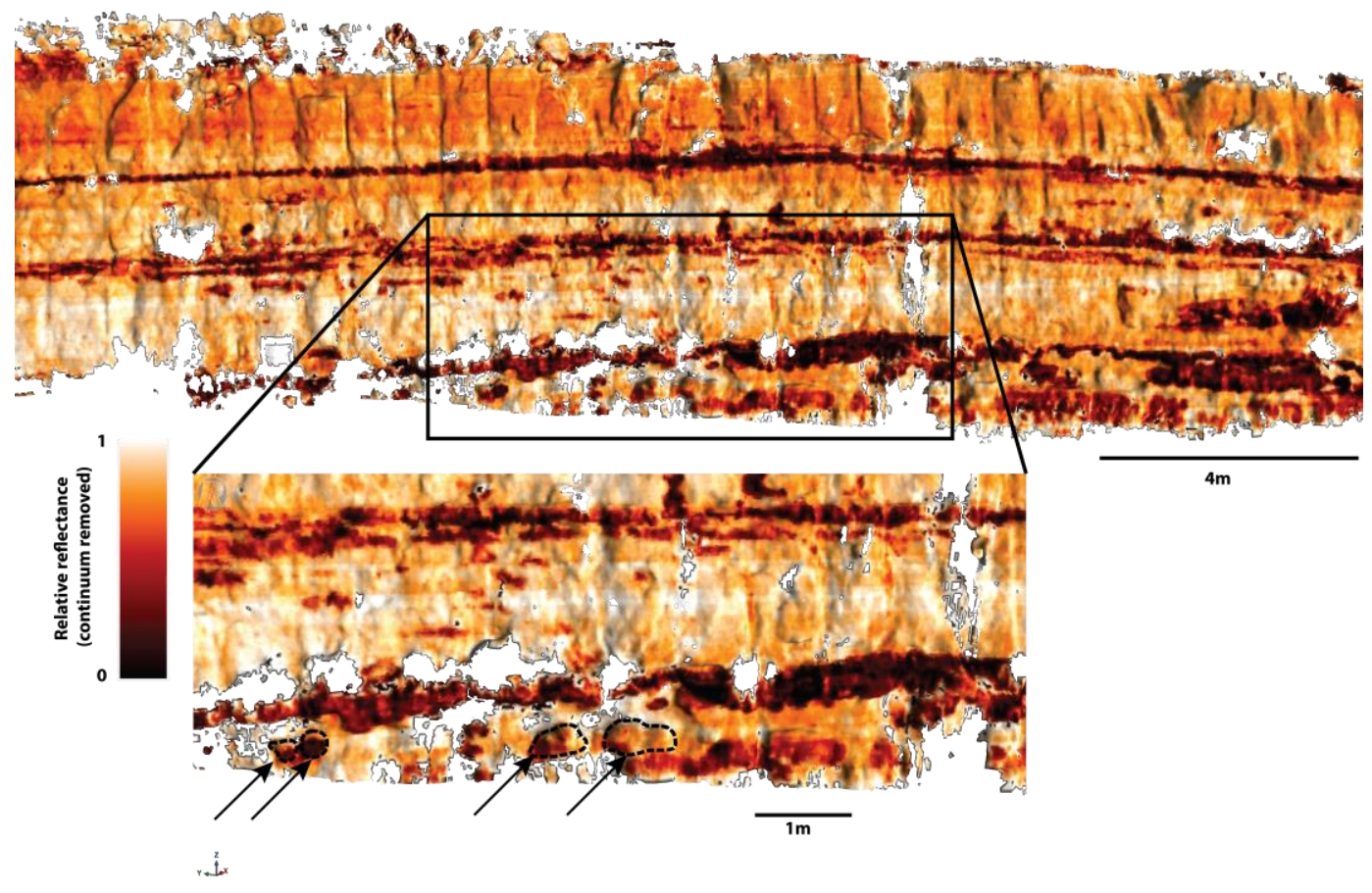

Figure 13 
A

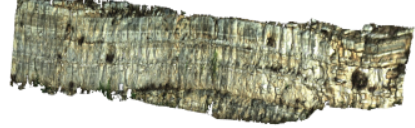

B
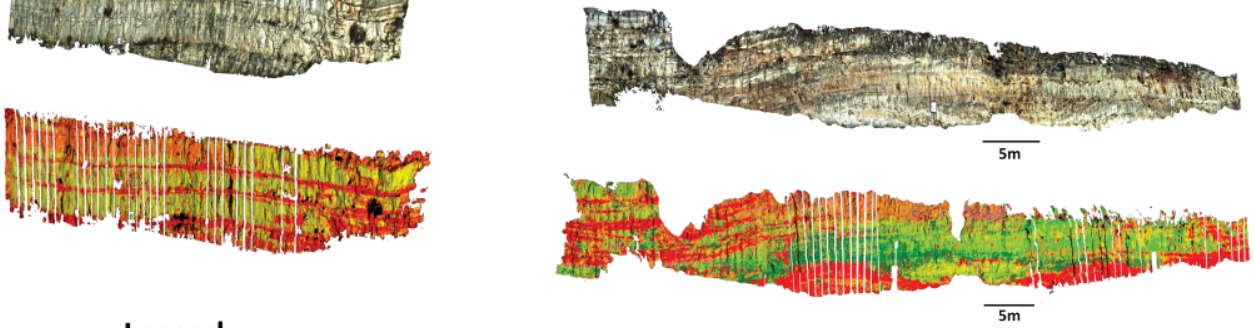

Legend

- Unclassified

- $100 \%$ Calcite: $22 \%$

- $100 \%$ Dolomite: $8 \%$

- $100 \%$ Chert: $<1 \%$

D 25\% Calcite $75 \%$ Dolomite: $13 \%$

c

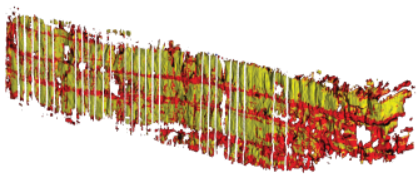

- Unclassified

$\square$ Chert

$\square$ Limestone
50\% Calcite 50\% Dolomite: $18 \%$

- 75\% Calcite 25\% Dolomite: $28 \%$

- 15\% Calcite 15\% Dolomite 70\% Chert

- 25\% Calcite 50\% Dolomite 25\% Chert: $<1 \%$

50\% Calcite 25\% Dolomite 25\% Chert: $9 \%$
15\% Calcite $70 \%$ Dolomite $15 \%$ Chert: $<1 \%$ - $70 \%$ Calcite $15 \%$ Dolomite $15 \%$ Chert: $2 \%$

- Masked

D

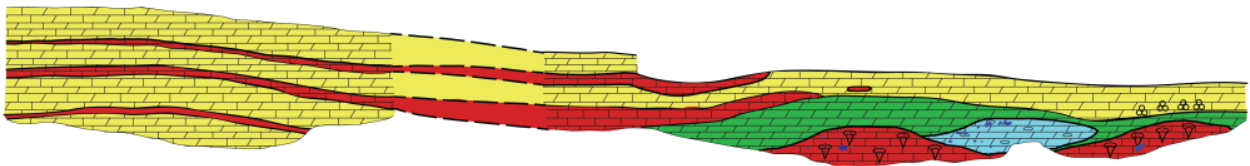

Legend

\begin{tabular}{|c|c|c|}
\hline Limestone & $\nabla$ & Rudist fossils \\
\hline Dolomite & 8 & Foraminifera \\
\hline Dolomitic limestone & - & Chert nodules \\
\hline Cherty dolostone & - & Carbonate nodules \\
\hline
\end{tabular}

Figure 14 
A Rudist bioherms

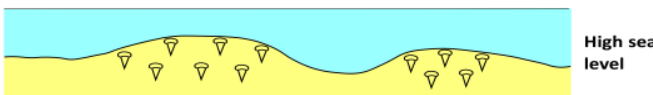

B Dolomitization

$$
\text { Legend }
$$

Figure 15 
A

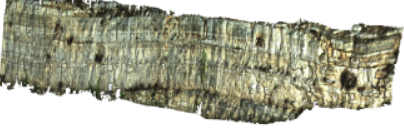

B
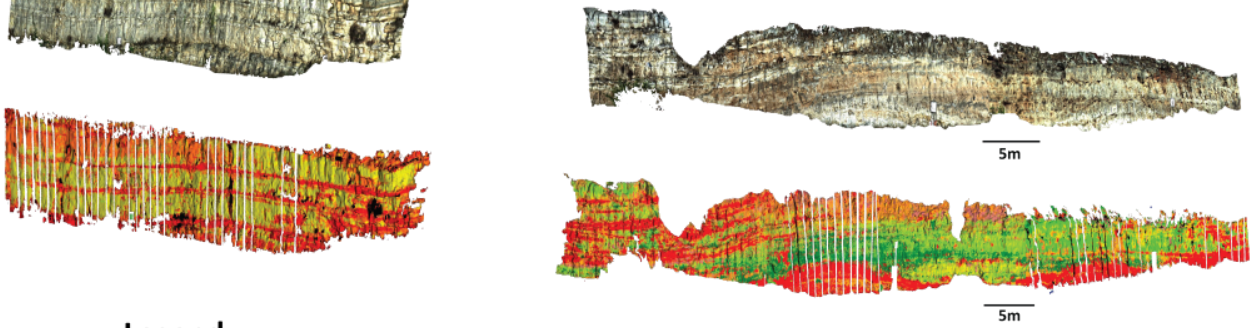

Legend

- Unclassified

- $100 \%$ Calcite: $22 \%$

- 100\% Dolomite: $8 \%$

- $100 \%$ Chert: $<1 \%$

D25\% Calcite $75 \%$ Dolomite: $13 \%$

c

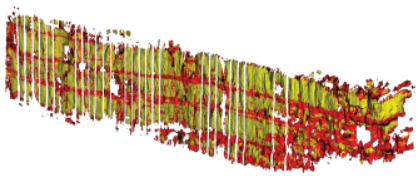

- Unclassified

$\square$ Chert

$\square$ Limestone
50\% Calcite 50\% Dolomite: $18 \%$

75\% Calcite $25 \%$ Dolomite: $28 \%$

- 15\% Calcite 15\% Dolomite 70\% Chert

- 25\% Calcite 50\% Dolomite 25\% Chert: $<1 \%$

50\% Calcite 25\% Dolomite 25\% Chert: $9 \%$
D15\% Calcite $70 \%$ Dolomite $15 \%$ Chert: $<1 \%$ - $70 \%$ Calcite $15 \%$ Dolomite $15 \%$ Chert: $2 \%$

- Masked

D

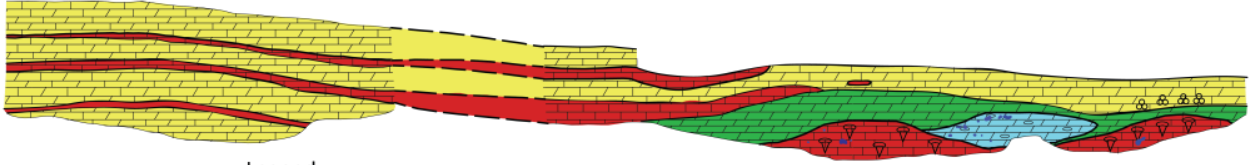

Legend

\begin{tabular}{|c|c|c|}
\hline Limestone & $\nabla$ & Rudist fossils \\
\hline Dolomite & 8 & Foraminifera \\
\hline Dolomitic limestone & - & Chert nodules \\
\hline Cherty dolostone & - & Carbonate nodules \\
\hline
\end{tabular}

\section{Graphical abstract}




\begin{tabular}{|l|l|l|}
\hline Mineralogy & Source location & Likely geologic formation and/or age \\
\hline Calcite & Minas, Nuevo Leon, Mexico & $\begin{array}{l}\text { Upper Jurassic Minas Viejas Formation (Vega } \\
\text { and Lawton, 2011) }\end{array}$ \\
\hline Dolomite & $\begin{array}{l}\text { Franklin Mine, Sussex County, New } \\
\text { Jersey }\end{array}$ & $\begin{array}{l}\text { Likely from hydrothermal vein (Palache, } \\
1937), \text { age unknown }\end{array}$ \\
\hline Quartz-Chert & Joplin, Missouri & $\begin{array}{l}\text { Likely Mississippian age (Tangier Smith and } \\
\text { Siebenthal, 1906), formation unknown }\end{array}$ \\
\hline
\end{tabular}

Table 1 


\begin{tabular}{lllllllllll} 
Sample & $\mathbf{1}$ & $\mathbf{2}$ & $\mathbf{3}$ & $\mathbf{4}$ & $\mathbf{5}$ & $\mathbf{6}$ & $\mathbf{7}$ & $\mathbf{8}$ & $\mathbf{9}$ & $\mathbf{1 0}$ \\
\hline Calcite & 83 & 5 & 76 & 82 & 78 & 70 & 17 & 53 & 53 & 26 \\
\hline Dolomite & 12 & 7 & 24 & 15 & 22 & 30 & 83 & 47 & 47 & 50 \\
\hline Chert & 6 & 88 & - & 3 & - & - & - & - & - & 24
\end{tabular}

Table 2 